\title{
Inventário Geológico do Patrimônio Construído no Litoral Norte do Estado de São Paulo, Brasil
}

Geological Inventory of the Built Heritage on the Northern Coast of São Paulo State, Brazil

\author{
KARLLA EMMANUELLE CUNHA ARRUDA ${ }^{1}$, MARIA DA GLÓRIA MOTTA GARCIA ${ }^{1}$, ELIANE \\ APARECIDA DEL LAMA ${ }^{1}$
}

\author{
1Universidade de São Paulo - USP, São Paulo - karllaemmanuelle@hotmail.com, mgmgarcia@usp.br, \\ edellama@usp.br
}

\begin{abstract}
Resumo
A geodiversidade está presente em todas as esferas do planeta, incluindo a urbana, desde a ocupação das cidades baseada no relevo, até os materiais utilizados nas construções. Este trabalho discorre sobre a relação entre o patrimônio construído e a geodiversidade dos materiais pétreos utilizados nas construções e monumentos de 4 municípios do litoral norte paulista: São Sebastião, Ilhabela, Caraguatatuba e Ubatuba. Foram analisadas em campo 31 construções na região, dentre as quais 13 receberam a denominação de Patrimônio Construído por apresentarem em sua construção materiais pétreos com aspectos geológicos relevantes. Com base no levantamento dos materiais pétreos pode-se concluir que a maioria dessas construções foram edificadas com pedra e cal conchífera locais, como é o caso de Ilhabela, com sienito, Ubatuba, com charnockito, São Sebastião, com gnaisse migmatítico, e Caraguatatuba, com gnaisse granítico milonítico. As formas de degradação da pedra podem ser visualizadas nessas construções, como intemperismo, eflorescência, umidade, manchamento, fraturas, aspecto brilhante e colonização biológica. A utilização desse patrimônio em termos de divulgação geocientífica mostra-se de grande eficácia para atingir a parte da população que não pode ou não possui o hábito de visitar parques e áreas naturais, pois passam a maior parte do tempo no meio urbano, sem contato direto com a natureza.
\end{abstract}

Palavras-chave: Patrimônio Construído; Geologia; Divulgação Geocientífica

\begin{abstract}
Geodiversity is present in all environments of the planet, including urban, from the occupation of cities based on relief, to the materials used in constructions. This work deals with the relationship between built heritage and geodiversity found in stone materials used in constructions and monuments in 4 municipalities on the northern coast of São Paulo State: São Sebastião, Ilhabela, Caraguatatuba and Ubatuba. A total of 31 buildings were analyzed in the region, of which 13 were categorized as Built Heritage based on the presence of stone materials with relevant geological aspects in their construction. Based on the inventory of the stone materials it can be concluded that most of these constructions were built with stones and shelly lime, the stones obtained mainly from the local geodiversity, as is the case of Ilhabela's syenite, Ubatuba's charnockite, São Sebastião's migmatitic gneiss, and Caraguatatuba's mylonitic granitic gneiss. Forms of stone degradation can be seen in these constructions, such as weathering, efflorescence, humidity, staining, fractures, shiny appearance and biological colonization. The use of this heritage in terms of geoscientific dissemination proves to be very effective in reaching the part of the population that cannot or is not in the habit of visiting parks and natural landscapes, since they spend most of their time in the urban environment, with no direct contact with nature.
\end{abstract}

Keywords: Built Heritage; Geology; Diffusion of geoscience 


\section{Introdução}

A geodiversidade está presente em todas as esferas do planeta, incluindo a esfera urbana, com a ocupação das cidades baseadas na geografia local, até os materiais utilizados nas construções e os espaços de lazer. O local de assentamento das cidades é definido de acordo com as facilidades geográficas, como topografia e hidrografia, solos e agricultura e, em alguns casos, pela presença de riquezas minerais.

O conceito de geodiversidade é usualmente definido como a gama natural de processos geológicos, geomorfológicos e características do solo, incluindo suas interrelações (Gray 2004). Entretanto, a geodiversidade de uma região tem importância não só geológica, mas também cultural, estando presente na memória social de um povo que, ao recordar uma determinada região, recorre às memórias associadas aos aspectos geográficos da paisagem (montanhas, colinas, praias, solo, etc.), incluindo as construções existentes naquele local.

Weber et al. (2016) consideram que edifícios, monumentos e outros recursos artificiais construídos com materiais geológicos são inteiramente consistentes com o conceito de geodiversidade. Em Brilha (2016), a denominação de "elementos do patrimônio geológico" - é dada para ocorrências geológicas ex situ com relevante valor científico, e "elementos da geodiversidade" - para ocorrências geológicas ex situ contendo outros valores relevantes (cultural, turístico, etc.). Embora adote termos diferentes, o autor considera esses elementos geológicos inseridos dentro do conceito de geodiversidade. Neste trabalho, o termo "patrimônio construído" é definido como construções ex situ de origem antrópica que apresentam em sua composição materiais geológicos e que possuam relativa importância para a geologia ou cultura local.

Este trabalho discorre sobre a relação entre o patrimônio construído nos municípios do litoral norte do estado de São Paulo e a diversidade litológica encontrada nessas construções e monumentos. Tem como principal escopo a disseminação da ideia de que os elementos da geodiversidade estão presentes no dia-a-dia das pessoas nas áreas urbanas e não apenas em áreas naturais distantes e isoladas. Algumas construções e ruínas representam importantes patrimônios históricos na região, apresentando um potencial para se explorar não só a história, mas também a geodiversidade, por meio dos materiais de construção que incluem diferentes rochas utilizadas de acordo com o momento econômico e cultural.

A divulgação da geodiversidade por meio da utilização das pedras nas construções urbanas vem ganhando cada vez mais espaço. Um dos primeiros trabalhos sobre a geologia urbana surgiu em Londres na década de 1980 (Robinson \& Bishop 1980, Robinson 1982, 1984, 1985, 1987, 1988, 1993, 1997), com a criação de trilhas geológicas urbanas, apresentando as rochas e minerais utilizados nas edificações de Londres.

No Brasil, a ideia de trilhas geológicas urbanas vem sendo trabalhada desde 2006 (Stern et al. 2006) e teve seguimento em Reys et al. (2008), Liccardo et al. (2008), Mansur et al. (2008), Del Lama et al. (2009), Philipp et al. (2009), Carvalho (2010), Augusto \& Del Lama (2011), Del Lama et al. (2015), Pinto (2015) e Nascimento et al. (2016). Entretanto, trata-se de uma área da geociência pouco divulgada, Del Lama et al. (2015) alertam para a influência da falta de recursos e o pouco investimento em cultura e educação como um fator limitante para a divulgação geocientífica no Brasil, assim como o pouco interesse da comunidade geológica em popularizar a ciência. Liccardo et al. (2012) afirmam que uma das principais limitações da divulgação das geociências é o distanciamento das pessoas em relação à natureza, visto que, segundo o último censo, $84,35 \%$ da população brasileira vive hoje em ambiente urbano (IBGE 2010).

Sendo assim, devido à dificuldade de deslocamento para áreas naturais em algumas regiões, pode-se levar um pouco da informação da geodiversidade presente no meio urbano, onde está concentrada a maior parte da população, tornando mais acessível o conhecimento geológico exemplificado pelos minerais e rochas existentes nas construções e monumentos, a fim de estimular o observador, por meio deste conhecimento, a conservar não só o patrimônio natural mas também o patrimônio construído. 
Alguns pesquisadores trataram de sistematizar o estado de conservação das rochas em edificações. Entre eles, destacam-se Aires-Barros (1991), que estudou as rochas portuguesas, e Fitzner $\&$ Heinrichs (2004), que avaliaram como ocorre a deterioração em rochas nos monumentos. Mais recentemente, os trabalhos estão inserindo estas edificações pétreas em roteiros geológicos. O principal objetivo deste tipo de estudos é acrescentar informação geológica ao turismo já existente nas cidades, inserindo um novo olhar sobre o patrimônio construído, também conhecido como Geoturismo Urbano, e consequentemente auxiliando na educação e divulgação das geociências.

Neste trabalho foram analisados e estudados em campo 31 pontos de construções representativas na história do litoral norte do estado de São Paulo. Dentre estas construções, apenas 13 receberam a denominação de patrimônio construído, sendo eles: Casa Esperança, Sítio Morro do Abrigo, Paróquia Nossa Senhora do Amparo, Sítio Histórico São Francisco, Paróquia Nossa Senhora D'Ajuda, Antigo Mercado de Escravos, Paróquia Matriz Santo Antônio, Relógio do Sol, Ruínas da Lagoinha, Ruínas do Ipiranguinha, Sobradão do Porto, Monumento em Homenagem ao Caiçara e Antiga Pedreira de Itamambuca. Como os demais pontos não apresentaram interesse geológico em seus materiais de construção e/ou de revestimento por não apresentarem rochas em bom estado de conservação ou com alguma relevância científica para a pesquisa, não foram incluídos neste trabalho.

\section{Caracterização da Área de Estudo}

O litoral norte do estado de São Paulo abrange uma área de aproximadamente 2.000 km2 (Figura 1).

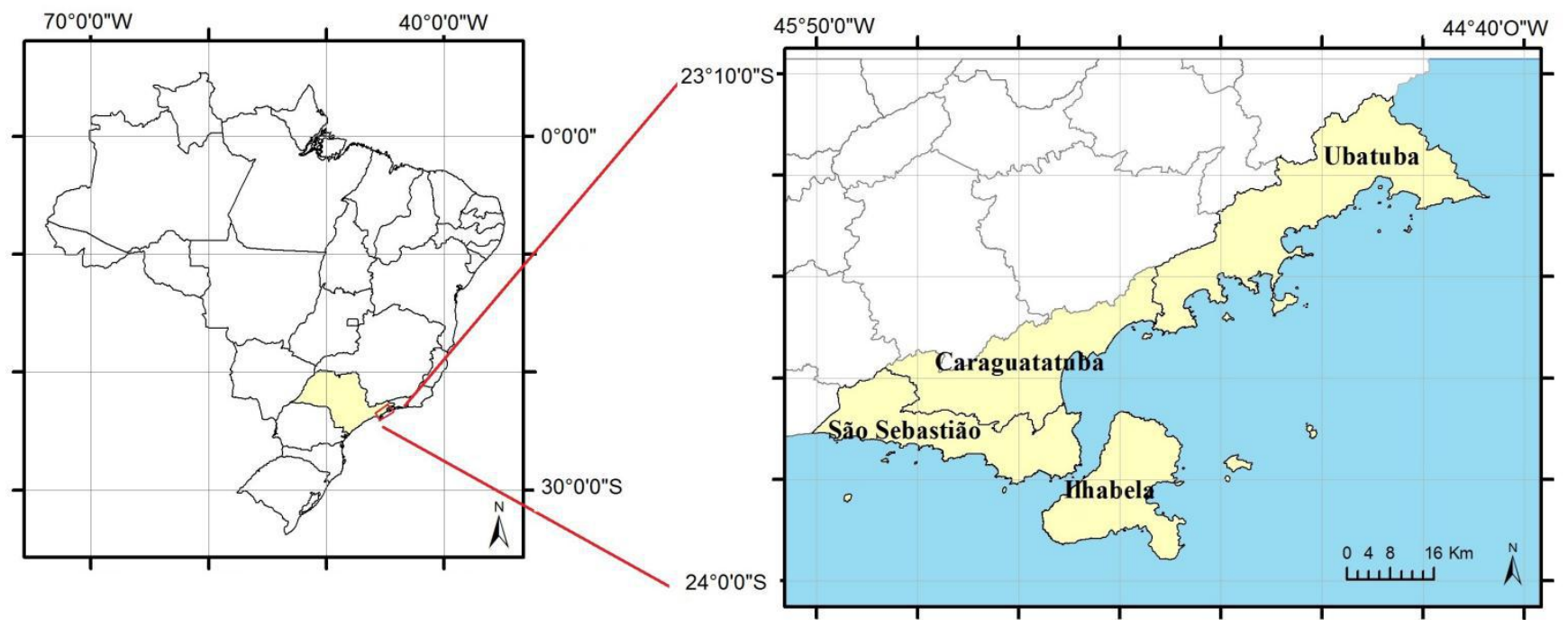

Figura 1 - Localização geográfica do litoral norte do estado de São Paulo, abrangendo os municípios de Ubatuba, Caraguatatuba, São Sebastião e Ilhabela.

\subsection{Geologia}

Geologicamente, a área de estudo está inserida como parte da Província Mantiqueira (Almeida et al. 1977), de idade Neoproterozoica, subdividida em várias unidades geológicas, incluindo o Domínio Costeiro (Heilbron et al. 2004), onde está mais precisamente a área de estudo. Esta unidade é delimitada, a norte, pela Falha de Cubatão e a sul, pela linha de costa e ilhas vizinhas. Sua evolução geomorfológica está relacionada ao estágio de reativação da plataforma brasileira, do Neojurássico ao recente (Almeida 1969).

Esse estágio de reativação tem relação direta com a fragmentação do Supercontinente Gondwana e abertura do Oceano Atlântico Sul, com a posterior formação da Serra do Mar e a forma da costa brasileira, assim como foi responsável pelo intenso e variável magmatismo representado 
pelos diques básicos e intermediários, e por stocks e diques de rochas alcalinas (Perrota et al. 2005) (Figura 2).

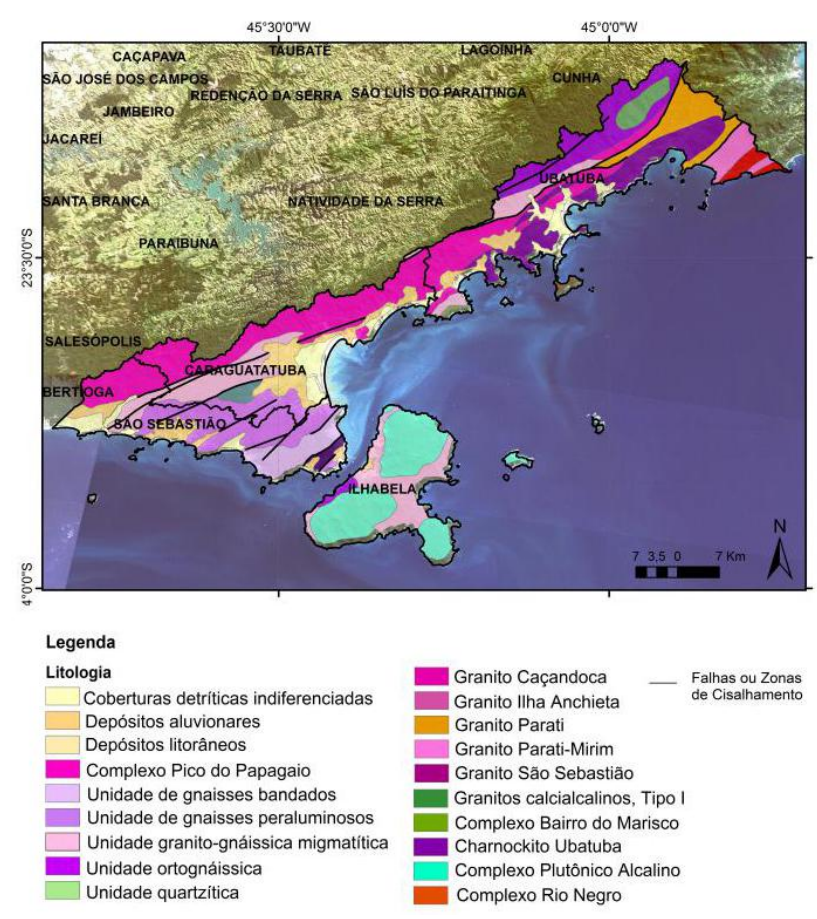

Figura 2 - Mapa Geológico da área de estudo. Adaptado de Perrota et al. (2005).

O Domínio Costeiro é composto de ortognaisses, gnaisses bandados, migmatitos, rochas granulíticas (São Sebastião), micaxistos, quartzitos arcoseanos, rochas calciossilicáticas, e intrusões tardi- a pós-tectônicas de granitoides e charnockitoides (Ubatuba) (Heilbron et al. 2004). Ocorrem ainda pequenos corpos de anfibolito derivados de toleítos continentais formados há 580 Ma e metamorfizados há 570 Ma (Dias Neto et al. 2006).

As coberturas cenozoicas estão representadas pelas áreas de planície costeira, onde ocorrem depósitos flúvio-lagunares, coluviais, detríticos com areia, silte, argila e cascalho, e depósitos litorâneos ou marinhos de areia, silte e argila.

O patrimônio geológico da região é constituído por 35 geossítios (Reverte 2014, Prochoroff 2014, Santos 2014, Arruda et al. 2015, Reverte \& Garcia 2016), representando majoritariamente rochas graníticas e gnáissicas. Foram inventariados também mirantes, de onde se podem observar e descrever aspetos geomorfológicos locais.

\subsection{Geomorfologia}

Os aspectos geomorfológicos da região são dominados pela Serra do Mar e caracterizados por um conjunto de escarpas que marcam a borda oriental dos terrenos pré-cambrianos do Planalto Atlântico (Cruz 1990), e pela planície costeira, com o município de Caraguatatuba possuindo a maior largura, cerca de $10 \mathrm{~km}$, do sopé da Serra do Mar ao oceano. A planície costeira desenvolve-se sobretudo em função do recuo das vertentes das escarpas serranas, das variações do nível do mar e do remanejamento e deposição dos sedimentos transportados pelas correntes marinhas na plataforma continental.

A região abrange uma parte do Parque Estadual da Serra do Mar - PESM, uma área de aproximadamente 332.000 hectares de conservação da Mata Atlântica dentro do estado de São Paulo, possuindo trilhas e atividades ecoturísticas em meio à elevada biodiversidade sobre as escarpas da Serra do Mar.

\subsection{Aspectos Socioeconômicos}

A história socioeconômica do litoral norte de São Paulo remete aos primórdios do período colonial e está diretamente ligada aos fatores geográficos e recursos geológicos disponíveis, como a instalação do porto em Ubatuba e posteriormente em São Sebastião, a exploração mineral e o turismo direcionado às zonas de praia a partir da década de 1950.

Segundo Scifoni (2006), são as atividades ligadas ao lazer e, dentro deste conjunto mais amplo o turismo de sol e mar, que movimentam a economia dos municípios do litoral norte, quais sejam São Sebastião, Ilhabela, Caraguatatuba e Ubatuba, e consequentemente a dinâmica da produção deste espaço geográfico. Os valores referentes à população flutuante anual nos 4 municípios são de 100.000 a 230.000 (Seade 2011), representando a importância do turismo na região.

A população na região cresce a uma taxa geométrica anual superior à média registrada para o estado de São Paulo (2,26\% a.a. e $1,32 \%$ a.a., respectivamente - Seade 2011). Associada a esta elevada taxa geométrica de crescimento anual da população fixa, soma-se - grande afluxo de turistas (população flutuante), principalmente durante a época de 
veraneio, sendo esta atividade a principal fonte de renda da região.

\section{Patrimônio Construído no Litoral Norte de São Paulo}

As 13 construções e monumentos selecionados para constituírem o patrimônio construído devido à importância histórica e cultural na região e pela constituição dos materiais pétreos estão representadas na Figura 3. A seleção levou em consideração também a acessibilidade (fácil localização, disponibilidade de acesso e tipo de propriedade), para que o objetivo final de oferecer informação geológica aos visitantes possa ser devidamente cumprido.

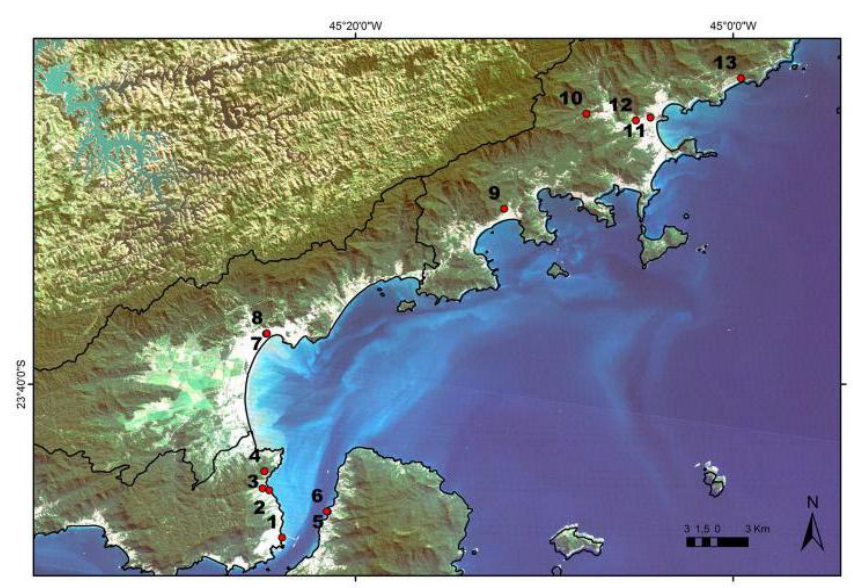

Figura 3 - Patrimônio construído no litoral norte do estado de São Paulo. Em São Sebastião: 1 - Casa Esperança; 2 - Paróquia Nossa Senhora do Amparo 3 Sítio Morro do Abrigo; 4 - Sítio Histórico São Francisco. Em Ilhabela: 5 - Paróquia Nossa Senhora D'Ajuda; 6 - Antigo Mercado de Escravos. Em Caraguatatuba: 7 - Paróquia Matriz Santo Antônio; 8 - Relógio do Sol. Em Ubatuba: 9 Ruínas da Lagoinha; 10 - Ruínas do Ipiranguinha; 11 Sobradão do Porto; 12 - Monumento em Homenagem ao Caiçara; 13 - Antiga Pedreira de Itamambuca.

A descrição dos materiais pétreos encontrados no patrimônio construído é tratada a seguir e sumarizada na Tabela 1. As formas de deterioração identificadas foram descritas com base no glossário do Icomos (2008).

\subsection{São Sebastião}

\subsubsection{Casa Esperança}

Casa Esperança, ou Casa com Teto Pintado, é um sobrado do século XVIII, localizada na Av.
Altino Arantes 32, no centro de São Sebastião, nas coordenadas 23K 459443/7367635. Foi resultado de uma economia paralela e subsidiária à mineração do interior da Colônia. De projeto e construção bastante apurados representa a arquitetura urbana colonial (Figura 4.a), construída em tijolo, pedra e cal, apresentando fachada simétrica e ornamentação em pedra, seguindo a padronização portuguesa contida nas Cartas Régias e nas Posturas Municipais, onde as ruas eram definidas pelos sobrados e casas térreas.

A casa pertencia a uma família de imigrantes italianos que montou um comércio chamado Esperança, a residência da família era no andar de cima. Recebeu o nome Casa com Teto Pintado pelo destaque das pinturas de seus tetos no andar térreo, representando cenas mitológicas, alegorias, paisagens e vistas do Rio de Janeiro no início do século XIX (Outeiro da Glória, Passeio Público, entrada da baía e Praça Quinze). Essas pinturas foram feitas durante a reforma de 1838, ocasião em que foram introduzidas as portas balcão e o gradil de ferro da sacada (Sectur 2015).

O sobrado também ficou conhecido pela decoração das três salas nobres do pavimento superior, além das portas trabalhadas em madeira e o gradil da escada.

Foi tombado pelo Iphan (Instituto do Patrimônio Histórico e Artístico Nacional) em 1955, e atualmente funciona como um espaço cultural no andar superior e estabelecimento comercial no piso térreo.

Como elementos geológicos na construção tem-se 0 batente das portas da casa, constituído a partir de dois tipos de gnaisse migmatítico (Figura 4.b), um mais máfico com concentrações de biotita (Figura 4.c) e outro mais félsico contendo cristais de granada. Os blocos de gnaisse no batente das portas, unidos por camadas de argamassa de cimento visivelmente mal acabada, causam prejuízo na estética da arquitetura original (Figura 4.d).

É possível observar que o desgaste da rocha é feito segundo a direção da foliação do gnaisse (Figuras 4.e e 4.f), que representam áreas de fraqueza da rocha e mais vulneráveis ao intemperismo e erosão. 
Arruda et al./Boletim Paranaense de Geociências 73-1 (2017) 15 - 33

Tabela 1 - Descrição do Patrimônio Construído do litoral norte de São Paulo.

\begin{tabular}{|c|c|c|c|}
\hline $\begin{array}{l}\text { Patrimônio } \\
\text { Construído }\end{array}$ & Município & $\begin{array}{l}\text { Litologias } \\
\text { dominantes }\end{array}$ & Justificativa de seleção \\
\hline Casa Esperança & \multirow{4}{*}{$\begin{array}{l}\text { São } \\
\text { Sebastião }\end{array}$} & $\begin{array}{l}\text { Gnaisse } \\
\text { migmatítico }\end{array}$ & $\begin{array}{l}\text { Presença de dois tipos de gnaisse migmatítico utilizado no batente } \\
\text { das portas. Um mais máfico com concentrações de biotita e outro } \\
\text { mais félsico contendo cristais de granada. } \\
\text { Desgaste da rocha seguindo a direção da foliação do gnaisse. }\end{array}$ \\
\hline $\begin{array}{l}\text { Paróquia Nossa } \\
\text { Senhora do } \\
\text { Amparo }\end{array}$ & & Gnaisse & $\begin{array}{l}\text { Batente das portas constituídos por gnaisse com cristais de granada } \\
\text { e grande quantidade de muscovita. }\end{array}$ \\
\hline $\begin{array}{l}\text { Sítio Morro do } \\
\text { Abrigo }\end{array}$ & & $\begin{array}{l}\text { Gnaisse } \\
\text { migmatítico }\end{array}$ & $\begin{array}{l}\text { Blocos de gnaisse migmatítico rico em biotita utilizado nos muros e } \\
\text { colunas da construção. }\end{array}$ \\
\hline $\begin{array}{l}\text { Sítio Histórico São } \\
\text { Francisco }\end{array}$ & & $\begin{array}{l}\text { Gnaisse } \\
\text { migmatítico }\end{array}$ & $\begin{array}{l}\text { Ruínas da construção, disposta em uma área de aproximadamente } \\
1.000 \mathrm{~m}^{2} \text {, constituídas predominantemente de blocos de gnaisse } \\
\text { migmatítico. }\end{array}$ \\
\hline $\begin{array}{l}\text { Paróquia Nossa } \\
\text { Senhora D'Ajuda }\end{array}$ & \multirow[t]{2}{*}{ Ilhabela } & Sienito & $\begin{array}{l}\text { Muro frontal constituído por blocos de gnaisse granítico, } \\
\text { apresentando porções pegmatíticas. Muro lateral constituído por } \\
\text { blocos de sienito, alguns apresentando auréola de alteração. A } \\
\text { parede externa da Paróquia tem sua construção original preservada } \\
\text { e exposta, apresentando blocos de sienito na construção. }\end{array}$ \\
\hline $\begin{array}{l}\text { Antigo Mercado } \\
\text { de Escravos }\end{array}$ & & Sienito & $\begin{array}{l}\text { Construção de importancia histórica contendo vestígios da parede } \\
\text { original, feito com blocos de rochas alcalinas porfiríticas e sienitos. }\end{array}$ \\
\hline $\begin{array}{l}\text { Paróquia Matriz } \\
\text { Santo Antônio }\end{array}$ & \multirow{2}{*}{$\begin{array}{l}\text { Caraguatatu } \\
\text { ba }\end{array}$} & $\begin{array}{l}\text { Gnaisse } \\
\text { milonítico }\end{array}$ & $\begin{array}{l}\text { Afloramento de gnaisse granítico milonítico de granulação grossa } \\
\text { com ocorrência de bandas de gnaisse de granulação mais fina, com } \\
\text { presença de enclaves. }\end{array}$ \\
\hline Relógio do Sol & & $\begin{array}{l}\text { Gnaisse } \\
\text { milonítico }\end{array}$ & $\begin{array}{l}\text { Base do monumento constituída por placas de granito oceolar, e } \\
\text { gnaisse granítico milonítico bastante estirado. }\end{array}$ \\
\hline $\begin{array}{l}\text { Ruínas da } \\
\text { Lagoinha }\end{array}$ & \multirow{5}{*}{ Ubatuba } & Charnockito & $\begin{array}{l}\text { Ruínas históricas constituídas por blocos heterogêneos de diversos } \\
\text { tamanhos e composições litológicas, predominantemente } \\
\text { charnockito, alguns blocos de granito porfirítico com cristais de } \\
\text { feldspato e blocos de gnaisse. }\end{array}$ \\
\hline $\begin{array}{l}\text { Ruínas do } \\
\text { Ipiranguinha }\end{array}$ & & Gnaisse & $\begin{array}{l}\text { Ruínas constituídas de blocos de gnaisse e sem presença de } \\
\text { argamassa, inteiramente lixiviada com o tempo. }\end{array}$ \\
\hline $\begin{array}{l}\text { Sobradão do } \\
\text { Porto }\end{array}$ & & $\begin{array}{l}\text { Gnaisse } \\
\text { facoidal }\end{array}$ & $\begin{array}{l}\text { Blocos de granada-biotita gnaisse facoidal, com granadas } \\
\text { centimétricas utilizado na fachada das portas. }\end{array}$ \\
\hline $\begin{array}{l}\text { Monumento em } \\
\text { Homenagem ao } \\
\text { Caiçara }\end{array}$ & & Charnockito & Base do monumento constituída por placas de charnockito porfirítico. \\
\hline $\begin{array}{l}\text { Antiga Pedreira } \\
\text { Itamambuca }\end{array}$ & & Charnockito & $\begin{array}{l}\text { Grandes blocos de charnockito extraídos pela mineração e } \\
\text { abandonados na área de uma antiga pedreira. }\end{array}$ \\
\hline
\end{tabular}

\subsubsection{Paróquia de Nossa Senhora do Amparo}

Está construção está localizada no bairro de São Francisco, em frente à praia de São Francisco nas coordenadas 23K 457674/7372448 (Figura 5.a). Trata-se de uma construção do Século XVII edificada em pedra e cal, por mão-de-obra escrava. O edifício passou por uma restauração em 1932 e foi tombado em 1971 pela Condephaat, consistindo atualmente em um Patrimônio Histórico Estadual.

A paróquia está inserida no tour histórico e cultural do Roteiro das Capelas no município e abriga um convento franciscano. As pedras dispostas na atual construção estão localizadas nos batentes de portas e algumas janelas, constituídas de gnaisse com cristais de granada e abundante muscovita (Figura 5.b). A figura 5.c destaca sinais de deterioração das pedras utilizadas nos batentes, como rachaduras e mal acabamento da argamassa entre os blocos. A figura 5.d mostra diferentes tipos de gnaisse (provavelmente substituição em alguma reparação) na porção inferior do batente ligados por argamassa, também mal acabada, sendo o gnaisse disposto abaixo mais rico em granadas e de coloração rosada, e o gnaisse disposto acima com uma maior presença de biotita, apresentando uma coloração mais acinzentada. 


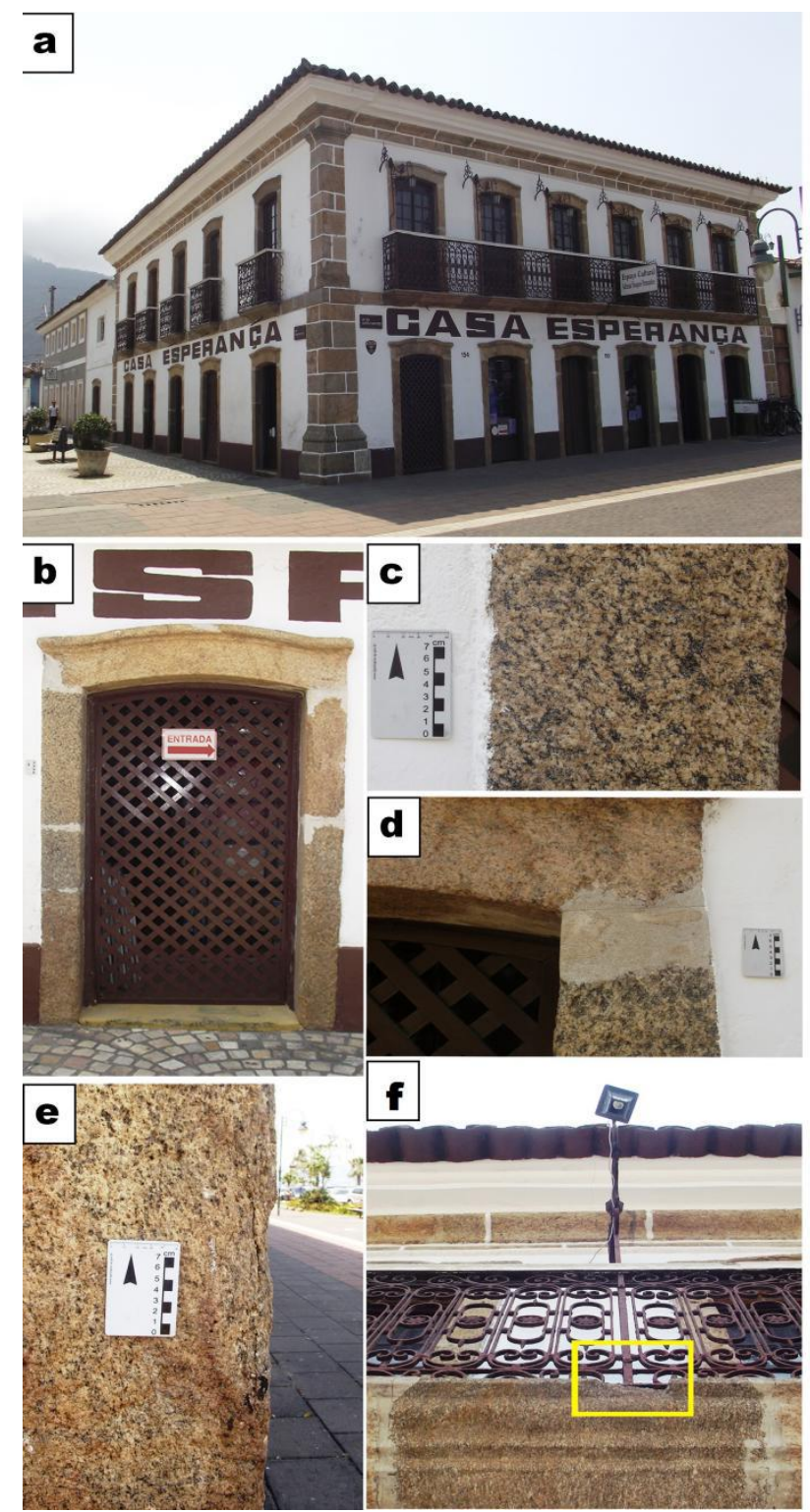

Figura 4 - a - Casa Esperança, ou Casa do Teto Pintado, arquitetura urbana colonial do século XVIII em São Sebastião - SP; ; b - batentes das portas constituídos por gnaisse migmatítico; c - gnaisse mais máfico, com concentrações de biotita; d - detalhe do acabamento inadequado de argamassa de cimento sobre o gnaisse; e desgaste da rocha seguindo as zonas de fraqueza da foliação do gnaisse; f - detalhe do desgaste da rocha gnássica utilizada no batente superior.

\subsubsection{Sítio Morro do Abrigo}

O Sítio histórico Morro do Abrigo (Figura 6.a) refere-se a ruínas de uma construção em pedra, tijolo e cal (Figura 6.b) da segunda metade do século XIX, localizado nas coordenadas 23K 457674/7372448, com acesso pela rua Guaratingueta 36 , em um bairro residencial e ocupando uma área de aproximadamente $1.000 \mathrm{~m} 2$.
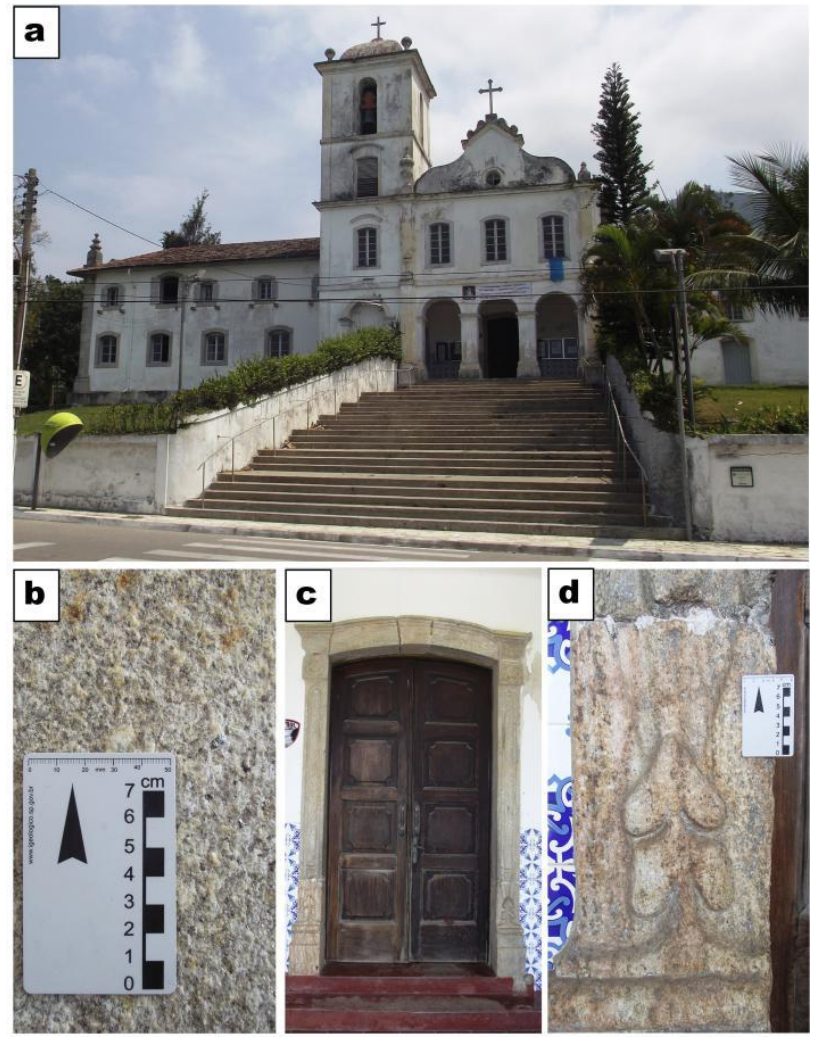

Figura 5 - a - Paróquia de Nossa Senhora do Amparo, São Sebastião; $b$ - detalhe do gnaisse utilizado no batente da porta com concentrações de granada e muscovita; c deterioração do gnaisse, com rachaduras na porção superior do batente; $d$ - utilização de diferentes tipos de rochas ligadas com argamassa mal acabada: acima, maior concentração de biotita e coloração acinzentada; abaixo, gnaisse rico em granada e coloração rosada.

Durante o ano de 2006, foi realizado um projeto de reconhecimento arqueológico com o objetivo de delimitá-lo e verificar as áreas de concentração de vestígios arqueológicos existentes em subsuperfície. Nesse caso, foi constatada a existência de um pacote arqueológico com cerca de $30 \mathrm{~cm}$ de profundidade e aproximadamente $25 \mathrm{~m} 2$, correspondendo a um bolsão de cultura material, onde os vestígios (cerâmica, faiança, vidro e grés) estão relacionados à segunda metade do século XIX, apontando para uma ocupação posterior ao Sítio São Francisco (Bornal 2008).

As ruínas da construção apresentam muros e colunas constituídas de blocos de gnaisse migmatítico ricos em biotita (Figuras 6.c). $\mathrm{Na}$ construção foram utilizados além de rochas, tijolos e argamassa conchífera (Figura 6.d). 
Atualmente, algumas colunas apresentam evidências de intervenções posteriores na construção, com tijolos (Figura 6.e), e camadas de argamassa e pinturas mais recentes nas paredes.
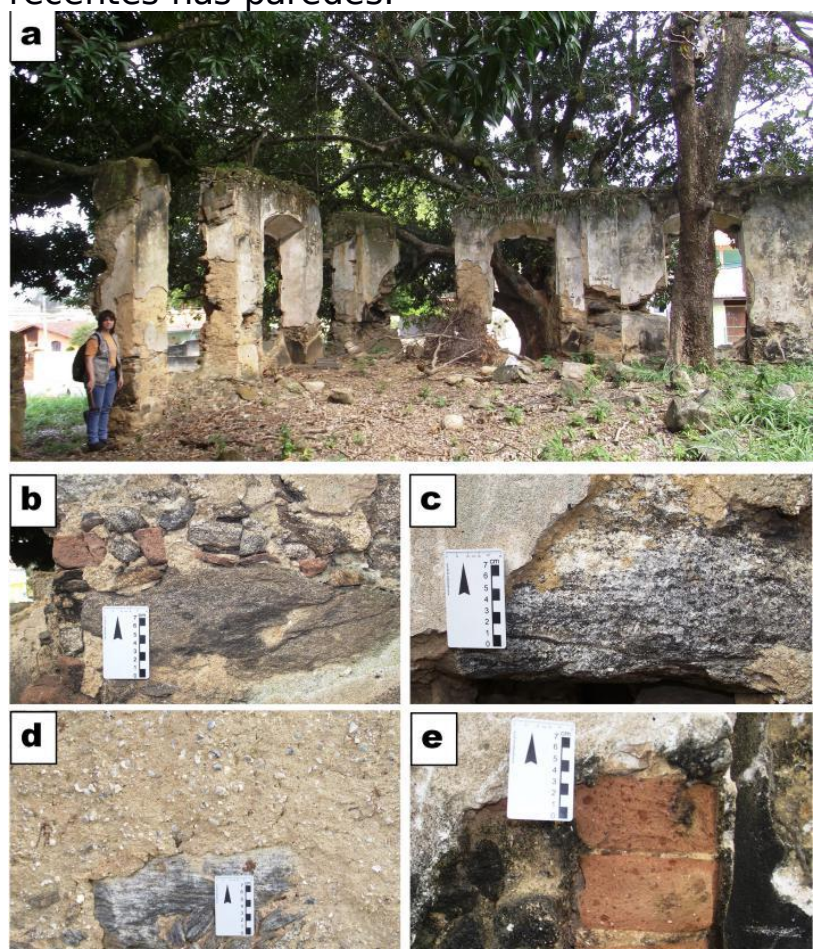

Figura 6 - Sítio Histórico Morro do Abrigo. a - Ruínas do Sítio Morro do Abrigo; b - construção original da parede feita com rochas, tijolos e cal conchífera; c - detalhe no bloco de rocha gnáissica; d - detalhe em argamassa conchífera; e - intervenção posterior na contrução realizada com tijolos.

\subsubsection{Sítio Histórico São Francisco}

As ruínas do antigo Sítio São Francisco, construído no século XIX, representam o conjunto de vestígios arqueológicos de construções (Figura 7.a) e restos construtivos de unidades habitacionais, religiosas e produtivas, caminhos, estradas, aquedutos e barragens, áreas de descarte de objetos e restos alimentares, áreas de plantio e postos de controle que se distribuem por aproximadamente $800.000 \mathrm{~m}^{2}$ (Bornal 2008).

Está localizado nas coordenadas 23K 457799/7374113, situado na Serra do Dom entre as cotas altimétricas 90 e $270 \mathrm{~m}$ e inserido no Parque Estadual da Serra do Mar. $\mathrm{O}$ acesso é feito pela rodovia Estadual SP-55, na Praia da Figueira em São Sebastião,. Do sítio tem-se a visão do canal de São Sebastião (Figura 7.b) e uma parte de Ilhabela.
Segundo Bornal (2008), vários fatores eram considerados fundamentais para a implantação de uma fazenda de cana ou café na área. A oferta de alguns recursos naturais constituía fator decisivo na escolha da área apta a receber as instalações de determinada unidade produtiva. Sendo assim, considerando as funções econômicas e sociais do sítio, seguramente suas instalações estão diretamente associadas a uma série de elementos, tais como a presença de mata, água, solo fértil e matéria-prima para as construções (pedra, barro e cal).

A construção está localizada parcialmente sobre afloramento de rocha gnáissica migmatizada (Figura 7.c), sendo os blocos de rocha utilizados nas construções provenientes deste local (Figura 7.d). Apesar de o tijolo ter sido utilizado em algumas partes da construção, os blocos de pedra são o principal material de construção, incluindo alguns pisos, como o do salão principal, revestido de blocos de gnaisse migmatítico. A rocha foi utilizada até mesmo para a colocação de arcos na construção referente ao fogão (Figura 7.e), onde comumente nas construções dessa época os arcos são construídos utilizando-se tijolos. É possível observar presença de colonização biológica em todas as porções das ruínas.

Em algumas partes da construção há vestígios do piso original de ardósia, porém o mesmo já foi quase completamente saqueado. Em algumas colunas foram utilizados vários materiais, como blocos de rochas, tijolos, cimento e argamassa conchífera (Figura 7.f). Camadas posteriores de argamassa cimentada também podem ser observadas (Figura 7.g). Na área do salão principal é possível observar adornos decorativos, de figuras humanas e aleatórias, constituídas de cimento e expostas nas paredes (Figura 7.h).

A captação de água do engenho era feita aproveitando-se a água da serra (Figura 7.i), em um sistema de engenharia advindo com a colonização portuguesa. Em um dos tanques da captação de água, é possível observar a superfície do bloco de rocha polida (Figura 7.j), que constituía um local para polimento de ferramentas. 


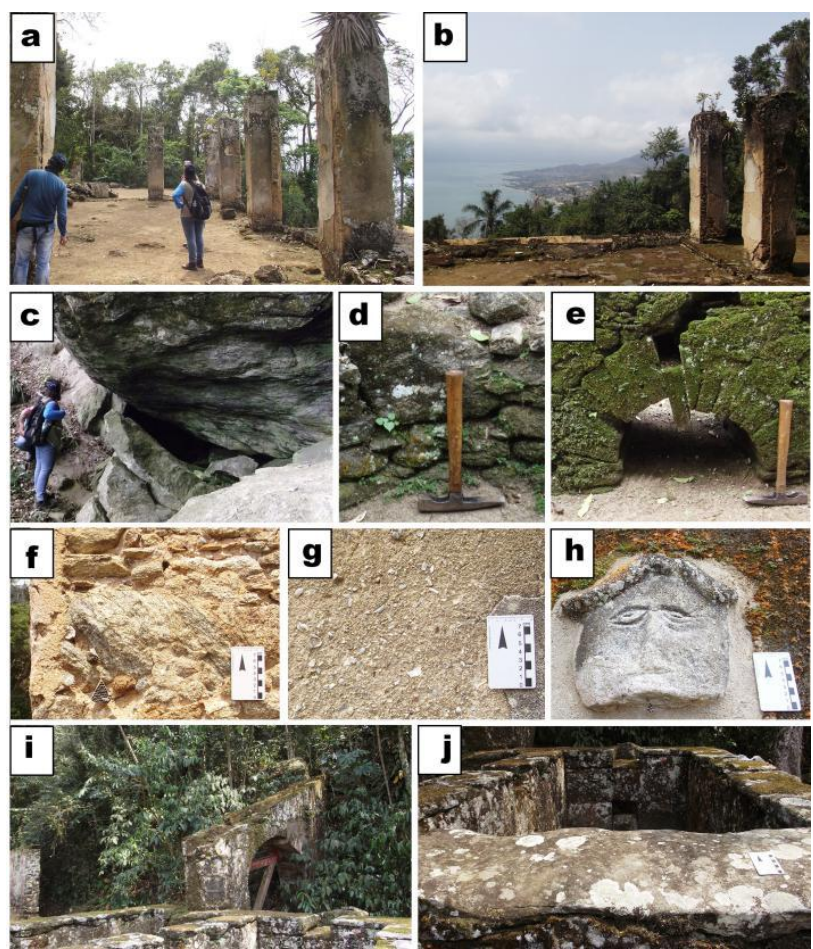

Figura 7 - Sítio Histórico São Francisco. a - ruínas do Sítio São Francisco; b - visão fornecida a partir do sítio para São Sebastião; c - afloramento de gnaisse; $d$ - blocos de gnaisse utilizados na construção; e - estrutura em arcadas feitas com blocos de rocha; $\mathrm{f}$ - colunas utilizando blocos de gnaisse; g - camadas de argamassa conchífera e de revestimento em cimento; $\mathrm{h}$ - adorno decorativo constituídas de cimento; i - sistema de captação de água da serra; j- porção do bloco rochoso polido, devido ao polimento de ferramentas.

\subsection{Ilhabela}

\subsubsection{Paróquia Nossa Senhora D'Ajuda}

A Paróquia Nossa Senhora D’Ajuda (Figura 8.a) é uma construção em pedra, tijolo e cal datada do século XVIII, localizada na Praça Prof. Alfredo Oliani 53 no centro de Ilhabela, com coordenadas 23K 463538/737019. Os dados a seguir apresentadossobre a história da paróquia foram obtidos dos folhetos informativos disponíveis na paróquia.

A história da construção da paróquia está associada aos primeiros moradores da llha de São Sebastião, que introduziram na cultura local uma forte devoção de origem portuguesa à Nossa Senhora D’Ajuda. Em 1697, o Padre Manoel Gomes Pereira mandou construir na ilha a primeira capela, mais tarde conhecida como Paróquia Nossa Senhora D'Ajuda. Com o passar do tempo, por falta de adequada conservação, a Paróquia foi se deteriorando e, por volta de 1793, foi realizada uma reforma por Matias José Bitencourt, que a reconstruiu quase que totalmente, seguida de outra reforma em 1800.

O estado atual da Paróquia Matriz de Ilhabela, como também é conhecida, é fruto do trabalho do escultor paulista Alfredo Oliani. A partir de 1950, este artista começou a arrecadar doações para a reforma da fachada, dos altares, da pintura do forro, dos quadros e colocação de novo piso.

Elementos geológicos presentes na construção original da paróquia representam a geodiversidade de llhabela e podem ser vistos nas pedras que constituem os muros da Paróquia. O muro frontal da paróquia é constituído por blocos de gnaisse granítico, de coloração cinza, às vezes rosado, e com algumas porções pegmatíticas (Figura 8.b). O muro lateral (Figura 8.c) é constituído por blocos de sienito, alguns apresentando auréola de alteração (Figura 8.d), e o piso é constituído por muscovita quartzito.

Uma gruta foi montada para a colocação de uma imagem de Nossa Senhora D'Ajuda. O altar sob a santa é constituído por um bloco de sienito com cerca de $2 \mathrm{~m}$ de diâmetro, assim como as paredes com blocos menores de sienito (Figura 8.e), rocha alcalina comum na Ilha.

A parede externa lateral da paróquia (Figura 8.f) tem sua construção original preservada e exposta, apresentando blocos de sienito, tijolos e concheiras (Figura 8.g). A proteção dessa parede é uma forma de manter conservado os registros históricos do período colonial no município.

$\mathrm{Na}$ área interna da paróquia tem-se a pia batismal, constituída de calcário fossilífero vermelho (Figura 8.h), e a escada do altar revestida de placas de mármore. No piso de entrada tem-se uma faixa de gnaisse, e todo o piso interno constitui um mosaico de rochas importadas com uma elevada diversidade litológica (Figura 8.i), adquiridas posteriormente para a reforma de 1950. Observam-se as seguintes rochas no piso: mármores de cores variadas - branco, cinza, rosa, esverdeado, amarelo ouro e preto, com dobras em algumas placas, além de travertino, Lioz, serpentinito e gnaisse vermelho bastante deformado. 


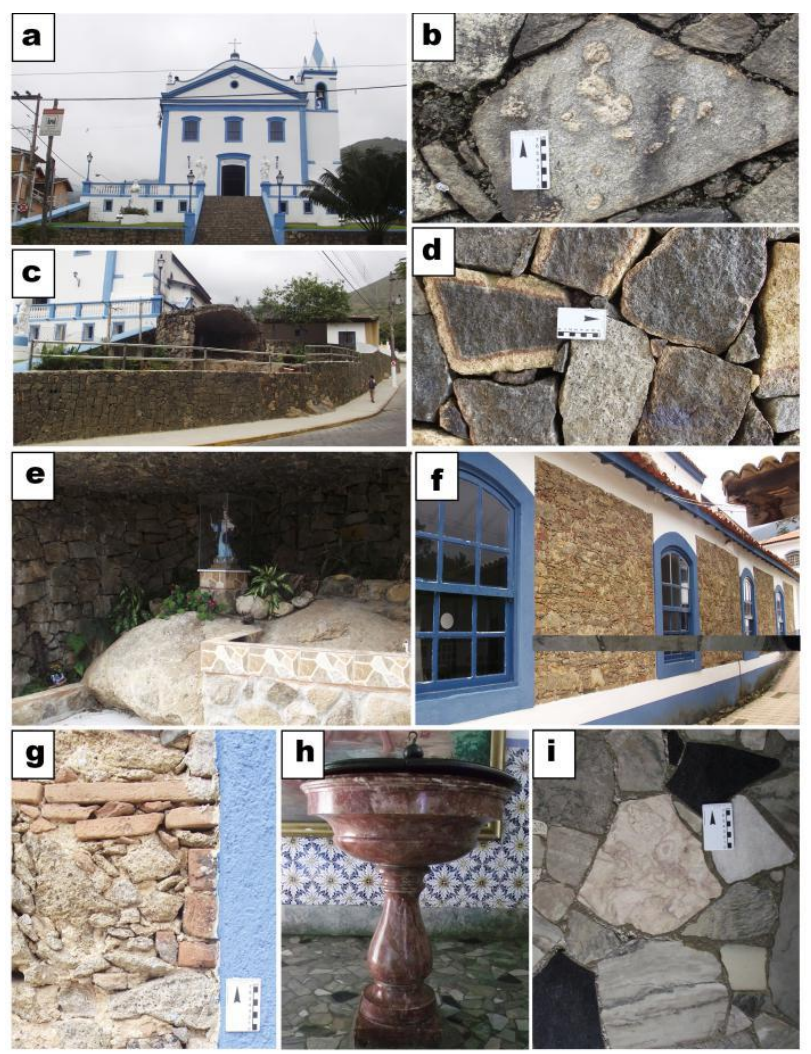

Figura 8 - Paróquia Nossa Senhora D'Ajuda. a - fachada; b - blocos de granito gnáissico localizados no muro frontal da paróquia, com porções pegmatíticas; c - muro lateral constituído de blocos de sienito; $d$ - detalhe nos blocos de sienito, alguns contendo auréola de alteração; e - gruta da Nossa Senhora D'Ajuda, composta por blocos de sienito; f - parede externa lateral da paróquia, com o muro original preservado; $g$ - muro lateral preservado composto por rochas, tijolos e argamassa conchífera; $\mathrm{h}$ pia batismal constituída de calcário fossilífero; i - detalhe do piso interno, mosaico de calcários, mármores diversos e sienitos.

\subsubsection{Antigo Mercado de Escravos}

O antigo mercado de escravos ficava situado em frente ao Canal de São Sebastião, na Praça Coronel Julião de Moura Negrão, centro histórico de Ilhabela, coordenadas 23K 463461/7370198, em local de fácil embarque e desembarque de mercadorias e de pessoas. Nesse período ainda não existiam pier ou atracadouros na vila, assim, mercadorias e pessoas eram desembarcadas diretamente na praia.

Nesse mercado eram comercializados diversos produtos consumidos na vila, porém o comércio mais movimentado era o de escravos, onde eram selecionados e vendidos para as principais fazendas da região (Bendazzoli 2014).
O prédio é atualmente ocupado por uma imobiliária e uma lanchonete (Figura 9.a), mas algumas das suas feições originais ainda estão preservadas, como colunas em pedras, paredes e arcos de passagem na parte interna e externa da construção (Figura 9.b).

Uma pintura em aquarela feita em 1827 por Jean Baptiste Debret (Figura 9.c), durante uma viagem sua à ilha, retrata a vila onde atualmente é a cidade de llhabela, com a antiga Paróquia da matriz, o prédio da cadeia,o fórum e a área da atual praça Cel. Julião de Moura Negrão, onde se localizava este mercado de escravos e o pelourinho, até então desconhecidos (Bendazzoli 2014).

O comércio de escravos na ilha possibilitou a formação de quilombos na região de Villa Bella (antiga Ilhabela). O centro histórico de Ilhabela foi palco das principais decisões políticas e administrativas da primeira vila, assistiu à chegada de estrangeiros e à defesa contra os corsários, abrigando muitos canhões para defesa da costa.

O antigo mercado de escravos de Ilhabela foi construído usando-se blocos de rochas, tijolos nos arcos das janelas e cal conchífera (Figura 9.d). As rochas utilizadas são as mesmas encontradas na ilha, rochas vulcânicas alcalinas, algumas porfiríticas (Figura 9.e), e a maioria composta de sienito, já bastante intemperizado (Figura 9.f).

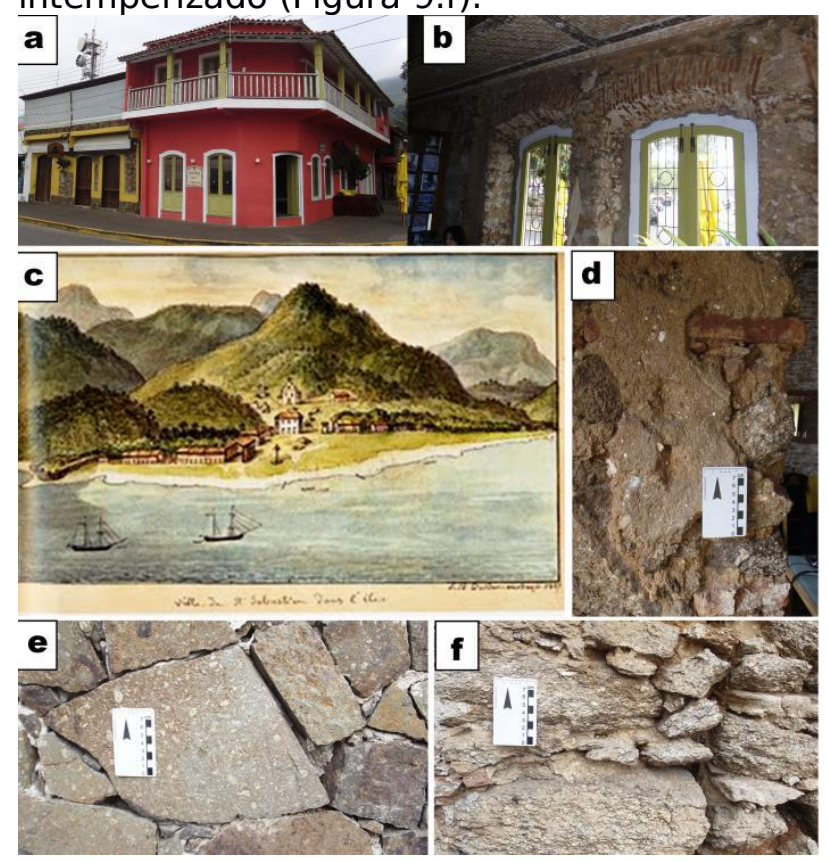

Figura 9 - Antigo mercado de escravos de llhabela. a configuração atual do antigo mercado de escravos, onde 
funciona um comércio; b - algumas áreas da construção permanecem preservadas; c - pintura de 1827 por Jean Baptiste Debret retratando a ilha; $d$ - detalhe da parede original da construção preservada, contendo pedras, tijolos e argamassa conchífera; e - blocos de rochas alcalinas porfiríticas; $f$ - blocos de rochas sieniticas intemperizadas.

\subsection{Caraguatatuba}

\subsubsection{Paróquia Matriz Santo Antônio}

A Paróquia Matriz Santo Antônio, foi primeiramente construída como a Capela de Santo Antônio de Caraguatatuba, em meados do século XVII, com alvenaria de tijolo. Após passar por diversas reformas, acabou sendo reconstruída em 1857, sob a responsabilidade do Pe. Vigário Manuel Antônio da Silva, sendo posteriormente reconstruída várias vezes. A data oficial de sua fundação é considerada como sendo 12 de junho de 1840, por Dom Manuel Joaquim Gonçalvez de Andrade. Ela localiza-se na Praça Cândido Motta, centro de Caraguatatuba, nas coordenadas 23K 457954/7387545.

Segundo a Fundação Educacional e Cultural de Caraguatatuba - Fundacc, em 1948 a Paróquia passou pela sua primeira grande reforma. Neste período, estava sob a responsabilidade do Pároco Frei Pacífico Wagner. A partir daí, passou por outras reformas e ampliações até ganhar o aspecto que tem hoje. A Paróquia está incluída na rota turística Passos dos Jesuítas - Anchieta..

A Paróquia Matriz Santo Antônio, embora não tenha revestimento exterior de materiais pétreos, apresenta em seu interior grande variedade de pedras ornamentais, como no piso, nas colunas, nas paredes internas e em alguns objetos.

O piso de entrada que dá acesso à Paróquia é constituído por mármore na configuração de pedra portuguesa na área externa (Figuras 10.b), enquanto na área interna o piso é constituído de mosaico de granito cinza equigranular com granulação fina e granito vermelho inequigranular (Figura 10.c). O piso na área externa lateral da Paróquia é constituído por placas de ardósia. As paredes e colunas localizadas na entrada da Paróquia são revestidas até meia altura por leucogranito contendo cristais de granada (Figura 10.d), similar ao Granito Carlos Chagas (Pinto et al. 2001), com arremate de uma faixa em granito vermelho.
Na área interna é possível observar alguns objetos constituídos por elementos geológicos, como a pia batismal (Figura 10.e), constituída por mármore cinza escuro e com a porção superior (mais escura) polida, devido ao constante passar de mãos dos fiéis, uma mesa de apoio na entrada constituída por granito porfirítico com megacristais de feldspatos com tonalidade mais alaranjada (Figura 10.f), e o pedestal de Nossa Senhora é constituído por granito vermelho com granulação mais grossa com relação ao piso, sendo a mesma rocha usada no piso e degraus do altar.

De frente para o altar, ao lado esquerdo, tem-se um afloramento de gnaisse granítico milonítico com granulação grossa, bastante estirado, com cerca de $3 \mathrm{~m}$ de diâmetro (Figura 10.g), que foi preservado durante a ampliação da área da Paróquia. No afloramento é possível observar também a ocorrência de bandas de gnaisse de granulação mais fina, com presença de enclaves (Figura 10.h). Algumas intervenções foram realizadas na área do afloramento, como a instalação de rampa com piso constituído por blocos cimentados de gnaisses nas porções finais do afloramento.

É possível observar algumas características de deterioração das rochas na área interna da Paróquia, tais como eflorescência de sais na parede constituída por leucogranito (Figura 10.i) e presença de umidade (Figura 10.j). No piso interno, constituído por granito cinza, há manchamento associado à umidade ascendente, clareando algumas porções da rocha (Figura 10.k).

\subsubsection{Relógio do Sol}

O Relógio do Sol, ou Monumento do 1응 Centenário (Figura 11.a), está localizado na Praça Cândido Mota, centro de Caraguatatuba, com coordenadas 23K 458044/7387544, próximo à Paróquia Santo Antônio e ao Museu de Arte e Cultura de Caraguatatuba, e possui cerca de 3,5 m de altura.

Foi construído em 1957, quando das comemorações do centenário da cidade. O monumento com base em pedra, representa o marco zero da cidade, e tem ilustrada uma vista oblíqua de Caraguatatuba (Figura 11.b), junto com os dizeres em latim Hohas non numero nisi serenas, que significa Só marco as horas serenas da vida (Figura 11.c). 

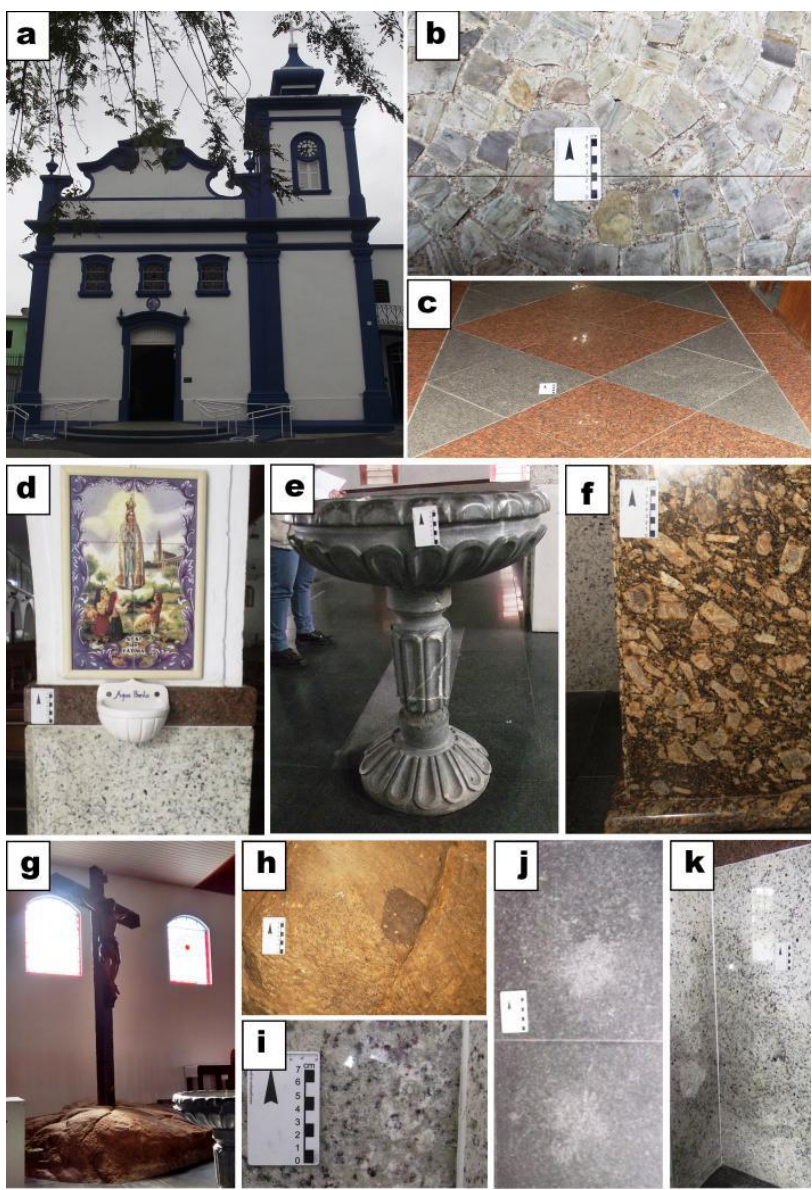

Figura 10 - Paróquia Matriz Santo Antônio. a - vista da fachada; b - pedras portuguesas no piso de entrada; c mosaico de rochas graníticas (cinza) e mármore (rosa) no piso interno; d - coluna revestida por leucogranito com cristais de granada; e - pia batismal de mármore escuro, com porção superior apresentando aspecto brilhante; $f$ mesa de apoio constituída por granitos porfiríticos, com megacristais de feldspato; $\mathrm{g}$ - afloramento de gnaisse granítico milonítico na área do altar; $\mathrm{h}$ - enclave no gnaisse; i - paredes de granito apresentando eflorescência de sais; $\mathrm{j}$ - parede de granito apresentando sinais de umidade; $\mathrm{k}$ - piso de granito apresentando manchamento devido à umidade ascendente.

O Relógio do Sol é protegido pela Lei Municipal de 13 de dezembro de 2006. Foi encomendado ao engenheiro Accacio Villalva a construção de um monumento que perpetuasse 0 sentimento do caraguatatubense naquele ano de comemoração do primeiro centenário de fundação da cidade.

O monumento possui a base composta por placas de granito oceolar cinza, com ocelos centimétricos (Figura 11.d) e os degraus compostos por gnaisse granítico milonítico bastante estirado (Figura 11.e). Como formas de alteração observadas, citam-se a presença de sujidade, colonização biológica (Figura 11.f), concreção, aspecto brilhante (devido ao constante passar de mãos dos visitantes) (Figura 11.g), lacunas, além de algumas pequenas fraturas.

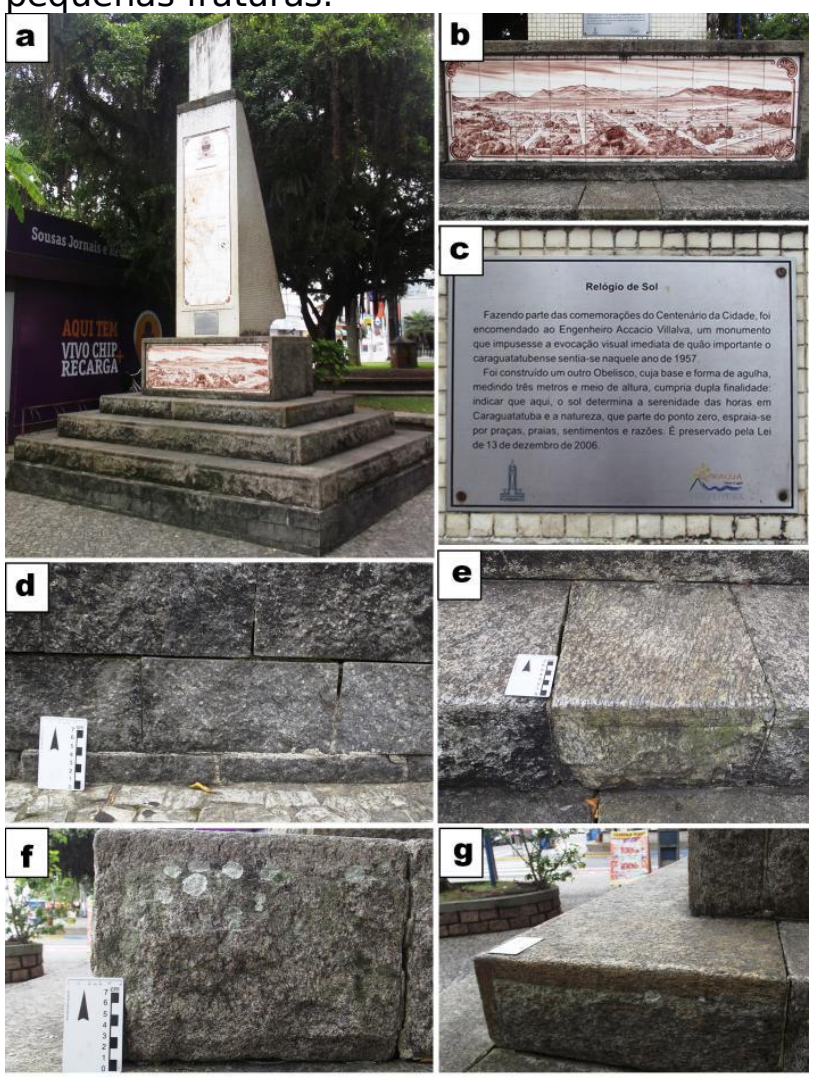

Figura 11 - Monumento do Relógio do Sol ou do 1 o Centenário. a - Relógio do Sol; b - vista oblíqua da cidade de Caraguatatuba; c - placa em aço simbolizando o 1 o Centenário da cidade de Caraguatatuba; d - base do monumento em granito ocelar; e - degraus do monumento constituído por placas de gnaisse granítico milonítico; f - presença de colonização biológica; g aspecto brilhante no gnaisse.

\subsection{Ubatuba}

\subsubsection{Ruínas da Lagoinha}

As Ruínas da Lagoinha são vestígios da antiga fazenda Bom Retiro (Figura 12.a), construída em 1828 com blocos de rochas, tijolos e argamassa conchífera, por um dos primeiros proprietários da Lagoinha, o engenheiro francês Stevenné, sendo classificada como engenho devido ao aqueduto existente e ao que restou das instalações de uma roda d'água (Fundart 2015a). Está localizada no bairro da Lagoinha nas coordenadas 23K 479619/7400177, e com 
acesso pela rua Engenho Velho no $\mathrm{km} 73 \mathrm{da}$ rodovia Rio-Santos.

As ruínas principais são constituídas por três paredões chegando à altura de aproximadamente $8 \mathrm{~m}$, constituídos por blocos rochosos de diversos tamanhos, apresentando arcadas com grandes janelas. $\mathrm{Na}$ lateral das ruínas principais está o muro que conduz o aqueduto, contendo arcadas constituídas por tijolos. Foram tombadas pelo Condephaat - Conselho de Defesa do Patrimônio Histórico, Arqueológico, Artístico e Turístico do Estado de São Paulo em 1985, com o objetivo de proteger e valorizar o patrimônio histórico do município.

Em 1989 o patrimônio histórico passou a ser administrado e mantido pela Fundart. O local é aberto para visitações e representa a história do município, sendo testemunha do período próspero em Ubatuba, quando em seu porto era negociada e exportada a produção do Vale do Paraíba. O local foi tambémcenário para filmes e ensaios fotográficos.

As instalações originais das Ruínas da Lagoinha foram construídas principalmente por blocos heterogêneos de rochas de diversos tamanhos e composições litológicas (Figura 12.b), com grande quantidade de charnockito (Figura 12.c), comum na região de Ubatuba e conhecido como Granito Verde Ubatuba, blocos de granito porfíritico com cristais de feldspato se destacando na rocha (Figura 12.d) e blocos de rocha gnáissica (Figura 12.e).

Em algumas porções é possível observar restos de argamassa de cal contendo grande quantidade de conchas, e tijolos constituindo algumas arcadas (Figura 12.f).

Atualmente, as ruínas encontram-se dominadas pela vegetação, contendo desde colonização biológica representada por fungos e musgos até arbustos, plantas epífitas e parasitas (Figura 12.g) e raízes de árvores de grande porte (Figura 12.h).

\subsubsection{Ruínas do Ipiranguinha}

As Ruínas do Ipiranguinha estão localizadas nas escarpas da Serra do Mar em Ubatuba (Figura 13.a), nas coordenadas 23K 486433/7409066. O acesso é feito pelo bairro do Ipiranguinha, pela rodovia Oswaldo Cruz no $\mathrm{km}$ 89, ou pela Cachoeira do Ipiranguinha (ou da Escada) (Figura 13.b). O bairro do
Ipiranguinha, onde estão localizadas as ruínas, servia de acesso ao Vale do Paraíba, sendo uma rota comum até meados do século XIX, em que as tropas de mulas carregadas levava e trazia pela serra os produtos de negócios e de troca.

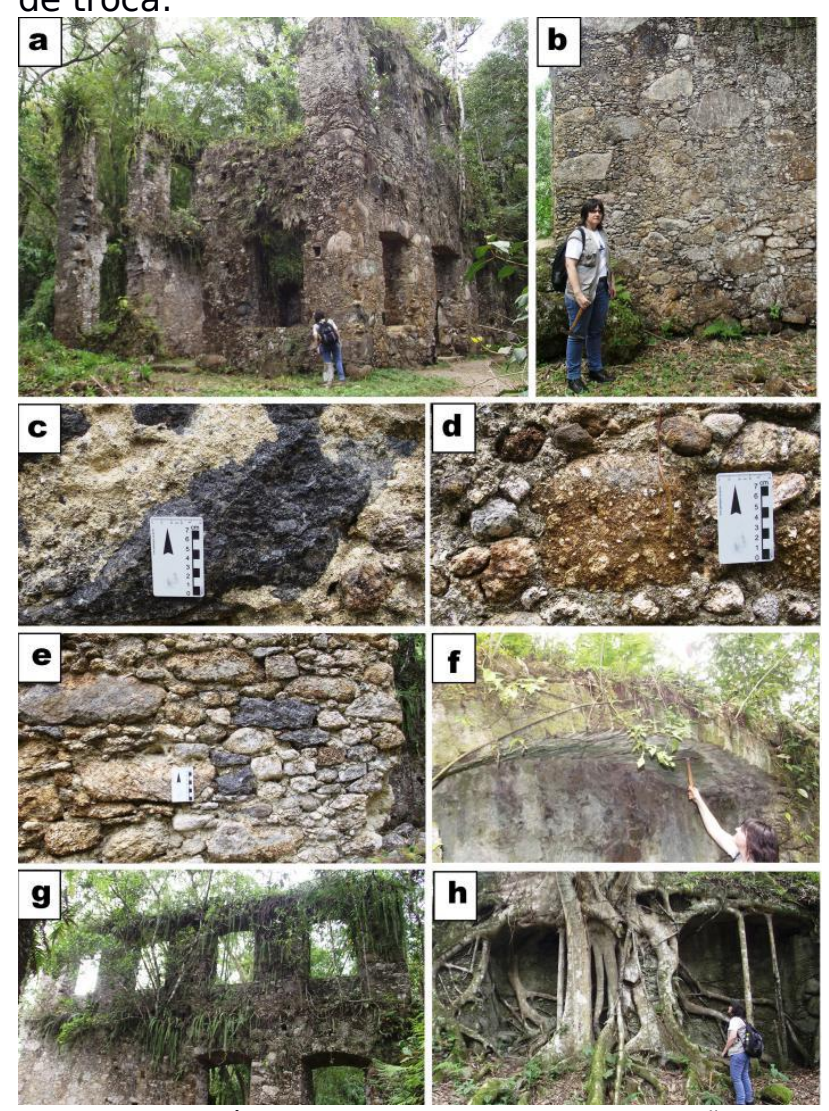

Figura 12 - Ruínas da Lagoinha, Ubatuba. a - Visão geral b - paredes constituídas por blocos heterogêneos de rocha; c - bloco de rocha charnockítica contendo áreas com revestimento em argamassa conchífera; $d$ - bloco de granito porfirítico; e - bloco de rocha gnáissica; f - arcada constituída de tijolos; $g$ - vegeteção recobrindo as ruínas; h - raízes de árvores de grande porte já estruturadas sobre as ruínas.

Essas ruínas são vestígios de uma construção em pedra, datada do século XVII, que formava uma fazenda com grande variedade de produtos e servia também para estocagem e armazenamento de material de escambo que vinham do Vale, permanecendo em atividade até 0 início do século $X X$. A fazenda do Sítio do Engenho, hoje, bairro do Ipiranguinha, representa um passado de fartura e riqueza nessa região.

A antiga fazenda do Sítio do Engenho, da qual hoje somente restam as ruínas, é prova inabalável de uma época de solidez econômica, tendo em vista que a arquitetura 
implantada em Ubatuba deu-se quase que totalmente em confecção de madeira e taipa, e a referida fazenda, a caráter das grandes e sólidas edificações, fora totalmente confeccionada em pedra.

Atualmente nas proximidades das ruínas funciona um bar (Figura 13.c) que atrai visitantes pela presença da Cachoeira do Ipiranguinha. Para se chegar até as ruínas deve-se seguir a trilha atrás do bar e caminhar por volta de $250 \mathrm{~m}$ (Figura 13.d), passando por alguns afloramentos de gnaisse com foliação milonítica (Figura 13.e). As ruínas são constituídas por muros de blocos de rochas gnáissicas e sem argamassa que foi, provavelmente, inteiramente lixiviada. As ruínas estão completamente envolvidas pela vegetação (Figura 13.f).
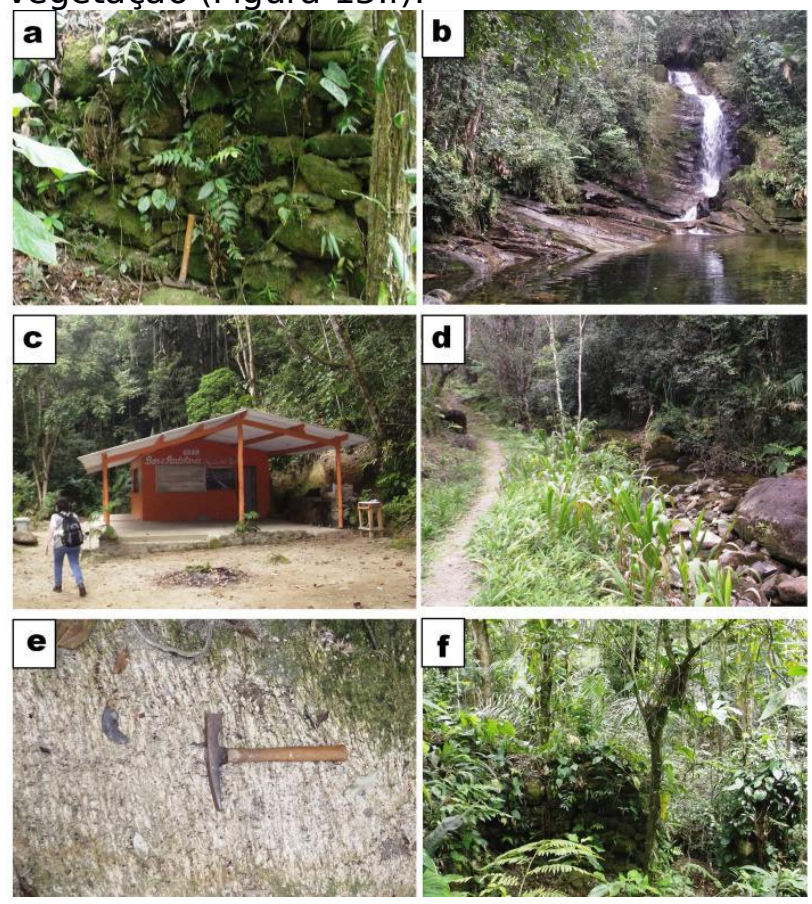

Figura 13 - Ruínas do Ipiranguinha. a - muro das Ruínas do Ipiranguinha; b - cachoeira do Ipiranguinha ou da Escada; c - bar localizado no início da trilha que leva às ruínas; $\mathrm{d}$ - trilha de $250 \mathrm{~m}$ até as ruínas; e - afloramento de gnáissica milonítico na trilha; $f$ - estado atual das ruínas tomada pela vegetação.

\subsubsection{Sobradão do Porto}

O Sobradão do Porto foi construído em 1846 (Figura 14.a) com utilização de alvenaria de pedra e argamassa, e pertencia a uma família tradicional da região. O prédio, composto por dois andares, era de uma arquitetura inovadora. Localiza-se nas coordenadas $23 \mathrm{~K}$
492550/7408714, na Praça Anchieta, centro de Ubatuba.

O primeiro pavimento servia como um armazém, onde se guardavam e negociavam toda a mercadoria de sacas de café, algodão, fumo, cana-de-açúcar e aguardente, tanto produzida em Ubatuba como em toda região do Vale do Paraíba. O segundo andar era utilizado como residência.

Com a decadência econômica de Ubatuba pelo fechamento de seu porto, muitos casarões foram abandonados, porém o Sobradão do Porto manteve-se soberano e, em 1926, passou a abrigar o Hotel e Restaurante Budapest (Fundart 2015b).

Em 1959 foi tombado pela Secretaria do Patrimônio Histórico, Arqueológico e Arquitetônico Nacional - Sphaan. Mais tarde, o valor histórico e arquitetônico do Sobradão do Porto também foi reconhecido, com o seu tombamento pelo Conselho de Defesa do Patrimônio Histórico, Arquitetônico, Artístico e Turístico do Estado de São Paulo Condephaat.

Em 1981, o Sobradão foi desapropriado pela Prefeitura Municipal e, em 1987, tornou-se a sede administrativa da Fundação de Arte e Cultura de Ubatuba - Fundart. Na década de 80 , foram realizados trabalhos de restauro da parte estrutural do prédio, com verbas do Ministério da Cultura sob a supervisão do Sphaan, de São Paulo. O contato com o Iphan - Instituto do Patrimônio Histórico e Artístico Nacional foi retomado em 2001, para a assessoria técnica especializada visando serviços emergenciais de conservação.

A administração da Fundart desocupou as dependências do andar superior do Sobradão em 2005, devido ao precário estado de sua estrutura. Em 2007 o contato com o Iphan resultou na elaboração de um projeto de restauro, projeto aprovado em 2009, iniciando-se a fase de captação de recursos para a sua execução

Na construção do Sobradão do Porto foram utilizados tijolos, pedras e argamassa. As pedras estão localizadas na parte externa da casa e nas fachadas das nove portas (Figura 14.b).

A rocha utilizada na confecção das fachadas das portas é um granada-biotita gnaisse facoidal, com granadas centimétricas (Figura 14.c), uma rocha ortoderivada bastante 
resistente ao intemperismo e que foi usado na construção de grande parte dos monumentos históricos da cidade do Rio de Janeiro, na forma de ornamentos, fachadas e molduras de portas e janelas. O uso dessa rocha no Sobradão do Porto pode estar relacionado com sua proximidade ao estado do Rio de Janeiro, de onde ela foi importada.

O uso do gnaisse facoidal na cantaria foi descrito por Jean Baptiste Debret em seu livro Viagem Pitoresca e Histórica ao Brasil, onde explica que ele é mais macio, menos caro e facilmente explorável, destinando-se às partes dos edifícios que deveriam ser esculpidas (Mansur et al. 2008).

O plano de foliação dos gnaisses nas colunas está na vertical (Figura14.d), e na parte superior das portas está na horizontal, o que facilita o desplacamento da rocha pela erosão. Algumas arcadas apresentam rejunte de cimento revestindo uma porção da rocha.

É possível observar presença de fraturas (Figura 14.e) na rocha, erosão segundo os planos de foliação do gnaisse e colonização biológica e sujidade em toda a construção (Figura 14.f).

No topo do edifício há também dois vasos de cerâmica portuguesa (Figura 14.g).

Defronte ao Sobradão há algumas informações sobre este colocadas em placas constituídas pelo Granito Verde Ubatuba (Figura 14.h).

O Sobradão do Porto representa o passado de prosperidade e glória de uma cidade que já abrigou o porto mais importante do país, sendo o único casarão que restou dos áureos tempos do café na segunda metade do século XIX em Ubatuba. Aberto à visitação, oferece espaço para exposições de arte, artesanato, fotografia, além de oficinas culturais, cursos e concursos que incentivam a produção artística, o resgate e valorização da cultura caiçara e suas tradições. É reconhecido como o principal patrimônio histórico de Ubatuba.

\subsubsection{Monumento em Homenagem ao Caiçara}

O Monumento ao Caiçara é representado por uma estátua de $10 \mathrm{~m}$ de altura, constituída de concreto sobre um pedestal revestido de rocha charnockítica, localizado em um trevo da rodovia BR-101 na entrada na cidade de
Ubatuba (Figura 15.a), nas coordenadas 23K $491236 / 7408440$.

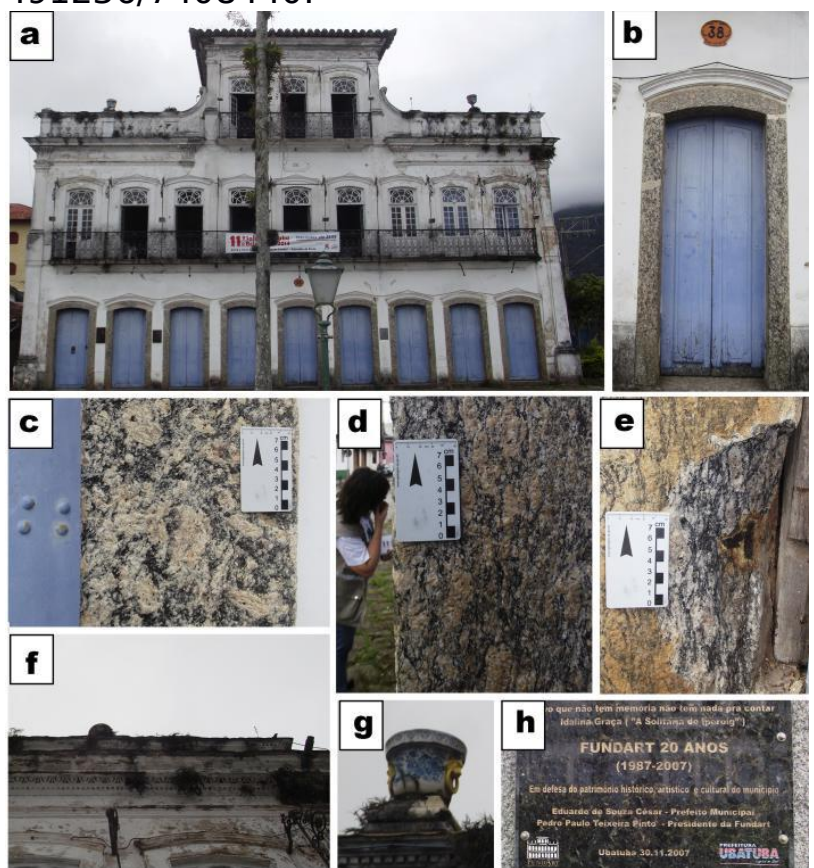

Figura 14 - Sobradão do Porto, Ubatuba. a - vista geral; b - batente das portas constituídas por gnaisse facoidal, às vezes com rejunte de cimento recobrindo parte da rocha; c - detalhe do gnaisse facoidal rico em granada; $d$ foliação vertical do gnaisse facoidal nas colunas das fachadas; e - coluna da fachada com perda de material; f - colonização biológica e sujidade presentes no edifício; $\mathrm{g}$-vaso de cerâmica portuguesa ornamentando o topo do edifício; h - placas informativas constituídas de rochas charnockíticas.

A estátua resgata a tradição dos caiçaras, antigos moradores do litoral paulista, representada pela figura de um pescador, sendo doada à comunidade em 2003, no aniversário de 366 anos de Ubatuba.

A base do monumento é constituída por placas de rocha charnockítica porfirítica (Figura 15.b), exibindo coloração verde escura típica da rocha, conhecida comercialmente como Granito Verde Ubatuba (Figura 15.c). Esta rocha é classificada como um ortopiroxênio-hornblenda monzogranito, e teve sua origem descrita em Freitas (1976) e Garda (1995) como magmática, datada em aproximadamente $565 \mathrm{Ma}$, como produto da fusão parcial das rochas de alto grau da crosta. Azevedo Sobrinho et al. (2011) associaram esta rocha à última gênese de granito no leste do estado de São Paulo.

Esta rocha ornamental é típica de Ubatuba e foi muito utilizada em monumentos e fachadas na região e também na cidade de 
São Paulo, como o pedestal da estátua de bronze de José Bonifácio na Praça do Patriarca, e em fachadas de alguns edifícios localizados no centro velho da cidade (Rodrigues 2012, Del Lama et al. 2015). Atualmente, a extração do charnockito de Ubatuba está proibida pelo fato de suas jazidas estarem em área de preservação ambiental e uma versão similar ado Granito Verde Ubatuba, proveniente do estado do Espírito Santo, é comercializada em seu lugar.

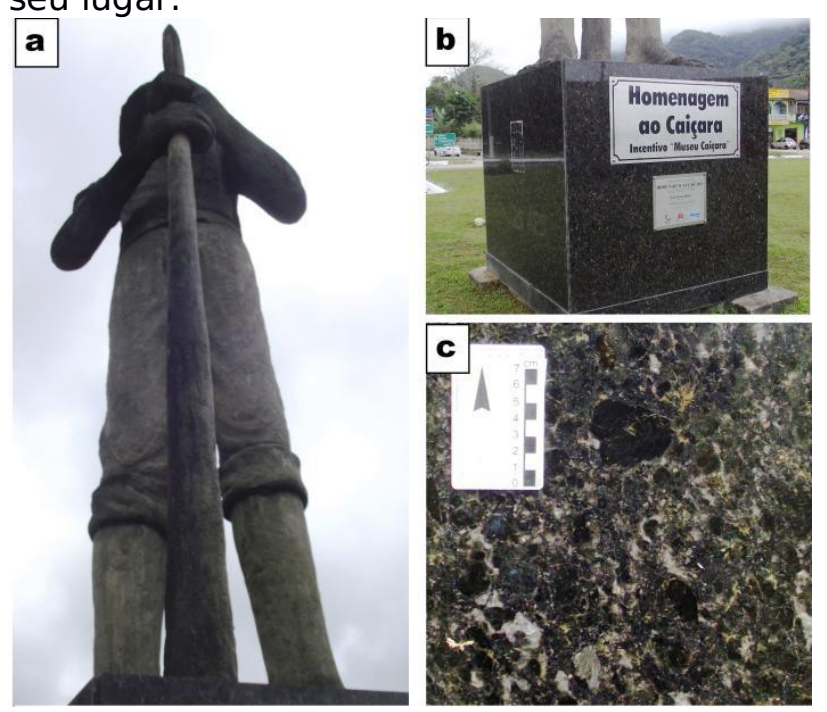

Figura 15 - Monumento ao Caiçara, Ubatuba. a - estátua representando um pescador caiçara com $10 \mathrm{~m}$ de altura, constituída em concreto; b - base da estátua revestida por rocha charnockítica; c - detalhe do charnockito (Granito Verde Ubatuba).

\subsubsection{Antiga Pedreira de Itamambuca}

A antiga pedreira de Itamambuca constitui-se em um dos locais de extração de charnockito, conhecido como Granito Verde Ubatuba, localizada na Praia de Itamambuca (Figura 16.a), nas coordenadas 23K 500694/741256, e o seu acesso dá-se pelo km 36 da rodovia Rio-Santos.

Este ponto foi descrito em Santos (2014) e definido como um geossítio de Ubatuba, pela importância que a rocha charnockítica possui na história e no desenvolvimento econômico e social no município de Ubatuba, além de representar importantes eventos da fase de aglutinação do Supercontinente Gondwana durante o Ciclo Brasiliano II (Hasui 2010).

Os charnockitos extraídos em Ubatuba chegaram a ser exportados para a Europa e Ásia. Segundo Santos (2014), existem pelo menos outros 160 pontos de antigas extrações de charnockitos, dentre as quais está a Pedreira Itamambuca, que representa uma das maiores áreas de extração da rocha. Com a criação do Parque Estadual da Serra do Mar em 1977, a extração da rocha foi proibida por estar inserida dentro da área de proteção ambiental. A interrupção da extração do charnockito gerou diversos problemas econômicos e sociais no município.

Na Praia de Itamambuca pode-se observar os remanescentes da antiga pedreira possuindo alguns blocos (Figura 16.b) com marcas de explosivos (Figura 16.c) utilizados na extração. Afloramentos e matacões de charnockito são encontrados nas áreas de extração da antiga pedreira no bairro Sertãozinho do Prumirim, além de um painel instalado no local contendo informações sobre o Granito Verde Ubatuba (Figura 16.d).

\section{Considerações finais}

Com base no levantamento dos materiais pétreos utilizados nas construções e monumentos do patrimônio construído do litoral norte do estado de São Paulo, pode-se concluir que as rochas utilizadas foram obtidas principalmente das rochas existentes na região ou exclusivas do próprio município, como é o caso de Ilhabela, com sienito; Ubatuba, com charnockito; São Sebastião, com gnaisse migmatítico; e Caraguatatuba, com gnaisse granítico milonítico. A utilização dessas rochas nestes municípios está relacionada com os tipos litológicos predominantes no Domínio Costeiro (Heilbron et al. 2004), composto principalmente por ortognaisses e gnaisses metapelíticos parcialmente migmatizados, sendo todo o conjunto cortado por inúmeros corpos de composição granítica sin a tardi-colisionais (Campanha \& Ens 1996).

A importância de um inventário do material pétreo utilizado em construções antigas e históricas vai além do valor geológico, sendo um valioso dado para a compreensão do registro histórico e cultural de um povo, representando não só os litotipos disponíveis, mas também o momento socioeconômico de uma população. A utilização de pedras locais sem polimento e alvenaria é vista nas construções mais antigas, como no Sítio Histórico de São Francisco e Paróquia Nossa Senhora D'Ajuda, que representam 
construções do período colonial. Com o desenvolvimento da região, as construções e reformas foram realizadas utilizando-se pedras ornamentais importadas, europeia e de outros estados do Brasil, representando uma era de crescimento socioeconômico da região. Monumentos mais recentes, como o
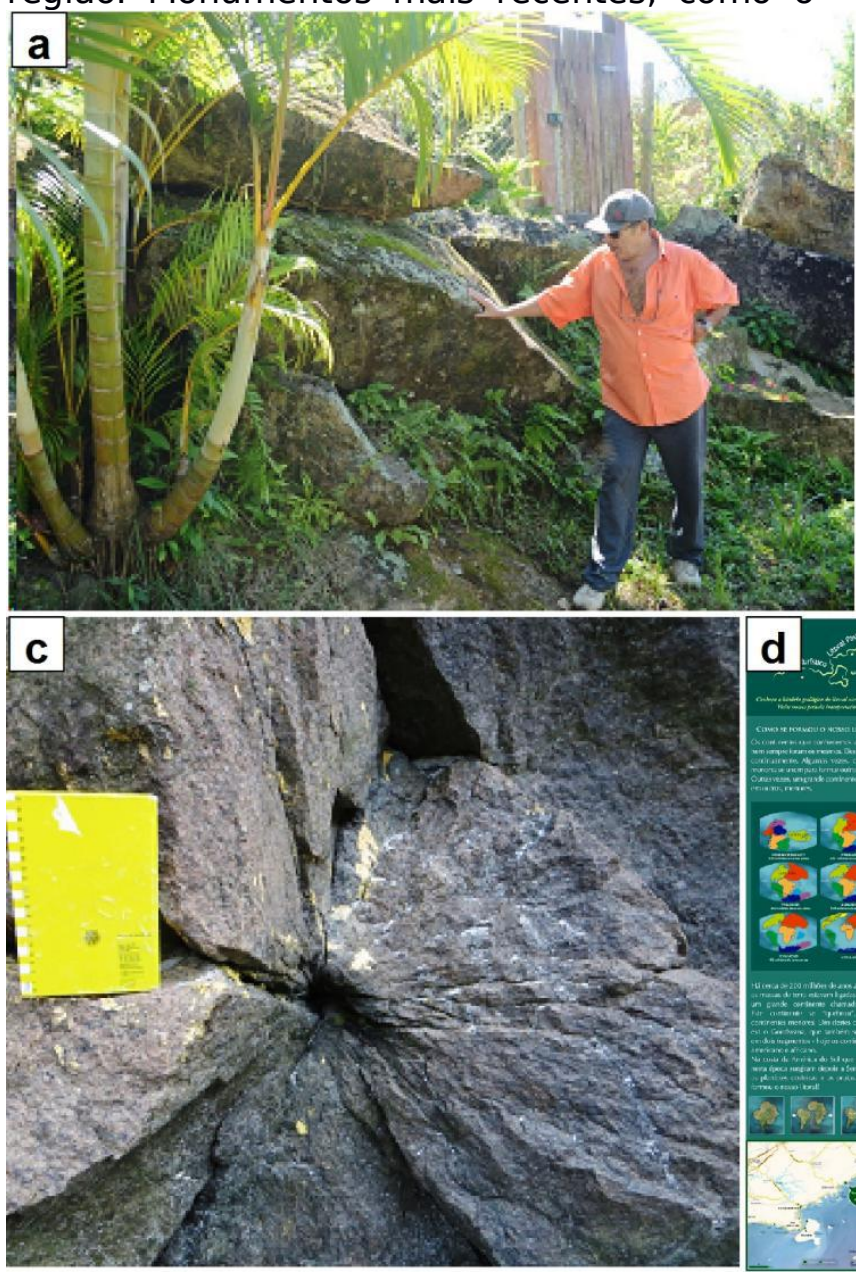

Monumento ao Caiçara, utilizam pedras ornamentais locais, valorizando os elementos geológicos da região. Tal valorização demonstra o desenvolvimento cultural associado ao reconhecimento de uma população acerca do seu valor histórico e econômico.
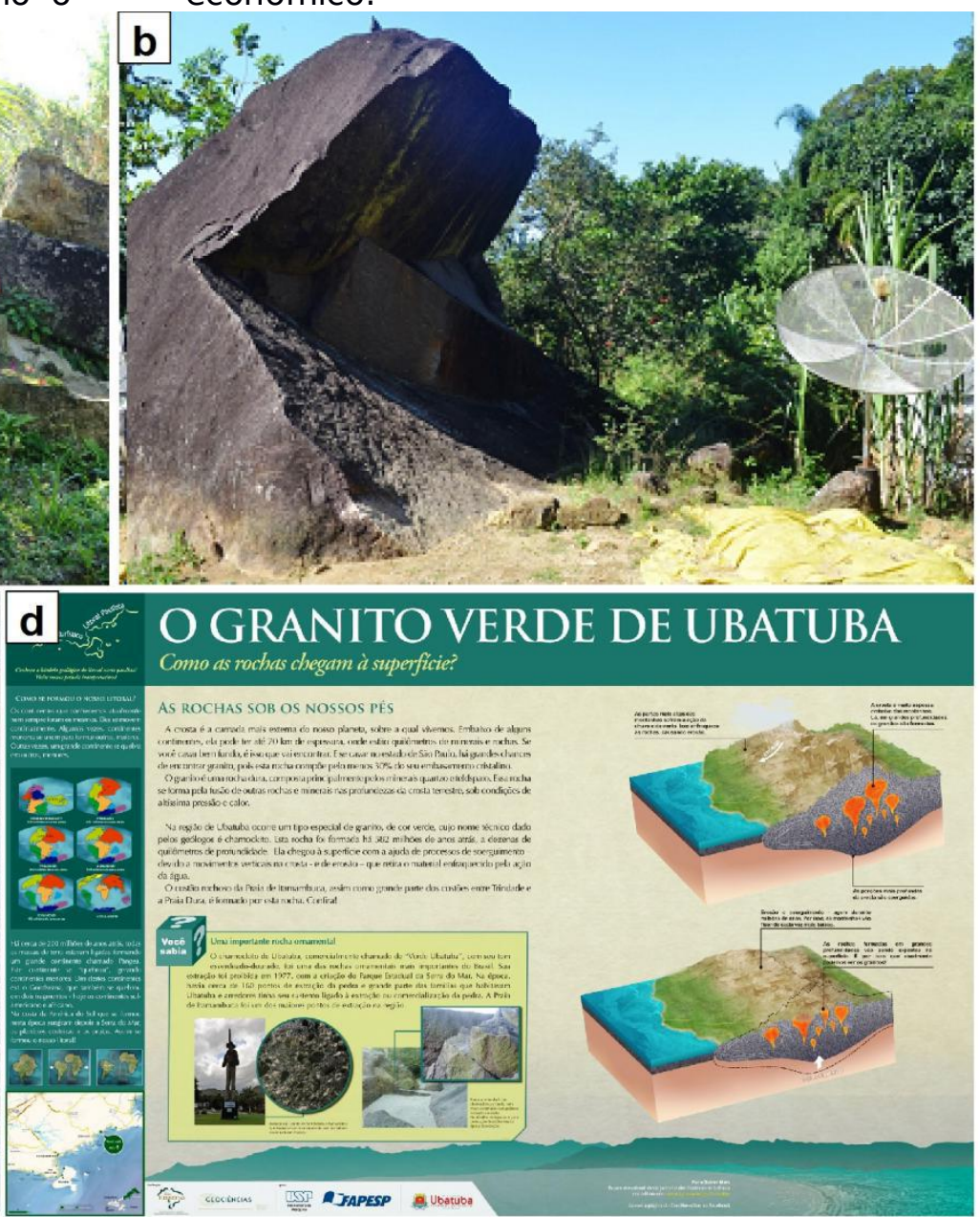

Figura 16 - Antiga Pedreira de Itamambuca. a - ruínas da antiga pedreira localizada na Praia de Itamambuca; b - blocos de charnockito apresentando exploração do período da mineração; c - marcas de explosivos nas rochas; $d$ - painel instalado na antiga pedreira contendo informações sobre o Granito Verde Ubatuba.

O presente inventário comporá, juntamente com patrimônio geológico e o patrimônio cultural, uma proposta futura de rota geoturística na região do litoral norte do estado de São Paulo. A utilização deste patrimônio como forma de divulgação geocientífica mostra-se de grande eficiência para abranger a parte da população que não pode ou não possui o hábito de visitar parques e áreas naturais, estando a maior parte do tempo no meio urbano sem contato direto com a natureza.

A utilização de informações litológicas do patrimônio construído é uma forma de diversificar e aprimorar o turismo já existente, além de subsidiar o uso didático voltado para a educação em geociências, já que o patrimônio histórico e cultural já é abordado em algumas escolas, e informações litológicas sobre esse patrimônio podem ser acrescentadas. A divulgação geocientífica 
auxilia no desenvolvimento cultural e pode trazer benefícios econômicos para uma região, valorizando o trabalho de guias de turismo com conhecimento sobre geociências, por exemplo, e levando mais turistas e curiosos do centro urbano para o meio natural, visto que, com a informação geológica recebida, eles podem ser induzidos a quererem conhecer outros lugares que tenham a geodiversidade como um fator de interesse principal. O próprio conhecimento geológico, mesmo que não aprofundado, e a própria informação histórico-cultural pode favorecer e incentivar ações de geoconservação, tanto do patrimônio construído quanto do natural, pois só se conserva aquilo que se conhece.

\section{Referências bibliográficas}

AIRES-BARROS L. 1991. Alteração e alterabilidade de rochas. Universidade Técnica de Lisboa, Instituto Nacional de Investigação Científica, Lisboa, 384p.

ALMEIDA F.F.M. 1969. Diferenciação tectônica da plataforma Brasileira. In: Congresso Brasileiro de Geologia, 23, Salvador, 1969. Anais, p. 29-46.

ALMEIDA F.F.M., HASUI Y., BRITO NEVES B.B., FUCK R.A. 1977. As províncias estruturais brasileiras. In: VIII Simpósio de Geologia do Nordeste, Campina Grande, PB, Atas, p.363-391.

ARRUDA K.E.C., GARCIA M.G.M., DEL LAMA E.A. 2015. Geological Heritage Inventory as a Subsidy for Geotourism: Caraguatatuba - São Paulo State, Brazil. In: The VIII International ProGEO Symposium, 2015, Reykjavik, Iceland. The VIII International ProGEO Symposium, 2015.

AUGUSTO W.C.B., DEL LAMA E.A. 2011. Roteiro geoturístico no centro da cidade de São Paulo. Terrae Didatica 7:29-40.

AZEVEDO SOBRINHO J.M., JANASI V.A., SIMONETTI A., HEAMAN L.M., SANTORO J., DINIZ H.N. 2011. The Ilha Anchieta Quartz Monzonite: the southernmost expression of Ca. 500 Ma post-collisional magmatism in the Ribeira Belt. Anais da Academia Brasileira de Ciências, 83(3): 891-906.

BENDAZZOLI C. 2014. O Antigo Mercado de Escravos de Villa Bella da Princesa. Disponível em: <http://ilhabelaarqueologica.blogspot.com.br/2014/0 1/o-antigo-mercado-de-escravos-de-villa.html> acessado em maio de 2015.

BORNAL W.G. 2008. Sítio Histórico São Francisco. Um estudo sob a ótica da Arqueologia da Paisagem. Tese de Doutorado, São Paulo: FFLCH/USP. 297p.

BRILHA J. 2016. Inventory and Quantitative Assessment of Geosites and Geodiversity Sites: a Review. Geoheritage 8:119-134.

CAMPANHA G.A.C., ENS H.H. 1996. Estruturação geológica da região da Serra do Juqueriquerê, São Sebastião, SP. Boletim IGc-USP 27:41-49.

CARVALHO H.L. 2010. Patrimônio geológico do centro histórico de Natal. Monografia (Graduação), Centro de Ciências Exatas e da Terra, Universidade Federal do Rio Grande do Norte. 105p.

CRUZ O. 1990. Contribuição geomorfológica ao estudo de escarpas da Serra do Mar. Revista do Instituto Geológico, 11(1):9-20.

DEL LAMA E.A., DEHIRA L.K., REYS A.C. 2009. Visão geológica dos monumentos da cidade de São Paulo. Revista Brasileira de Geociências. 39(3):409-420.

DEL LAMA E.A., BACCI D.C., MARTINS, L., GARCIA M.G.M., DEHIRA L.K. 2015. Urban Geotourism and the Old Centre of São Paulo City, Brazil. Geoheritage 7:147-164.
DIAS NETO C.M., FONSECA P.E., MUNHÁ J., EGYDIO SILVA M., RIBEIRO A. 2006. A estrutura em flor (flower structure) do Complexo Costeiro (Faixa Ribeira) em São Sebastião (São Paulo, Brasil). Cadernos Laboratório Xeolóxico de Laxe, La Curuña, v. 31, p. 105-125, 2006.

FITZNER B., HEINRICHS K. 2004. Photo Atlas of weathering forms on stone monuments. Disponível em: <http://www.stone.rwth-aachen.de>. Acesso em: 25 jun. 2007.

FREITAS R.O. 1976. Definição petrológica, estrutural e geotectônica das cintas orogênicas antigas do litoral norte do estado de São Paulo. Boletim IGc, 1:1-175.

FUNDART - FUNDAÇÃO DE ARTE E CULTURA 2015a. Ruínas da Lagoinha. Disponível em: $<$ http://fundart.com.br/dt_portfolio/ruinas-da-lagoinha / $>$ acessado em junho de 2015.

FUNDART - FUNDAÇÃO DE ARTE E CULTURA 2015b. Sobradão do Porto. Disponível em: < http://fundart.com.br/dt_portfolio/sobradao-do-porto/ $>$ acessado em junho de 2015.

GARDA G.M. 1995. Os diques básicos e ultrabásicos da região costeira entre as cidades de São Sebastião e Ubatuba, Estado de São Paulo. Tese (Doutorado), Instituto de Geociências, Universidade de São Paulo, São Paulo, p. 349.

GRAY M. 2004. Geodiversity: valuing and conserving abiotic nature. John Wiley \& Sons. 508p.

HASUI Y. 2010. A grande colisão pré-cambriana do sudeste brasileiro e a estruturação regional Geociências, UNESP, São Paulo, v.29, n.2, p.141-169.

HILBRON M., PREDOSA-SOARES A.C., CAMPOS NETO M.C., SILVA L.C., TROUW R.A.J., JANASI V.A. 2004. Província Mantiqueira. In: Mantesso-Neto et al. (Org.) - Geologia do Continente Sul-Americano - Evolução da Obra de Fernando Flávio Marques de Almeida, p. 203-234.

IBGE - INSTITUTO BRASILEIRO DE GEOGRAFIA E ESTATÍTICA 2010. http://www.censo2010.ibge.gov.br, Acessado em 25 de agosto de 2011.

ICOMOS - INTERNATIONAL COUNCIL ON MONUMENTS AND SITES 2008. Glossário ilustrado das formas de deterioração da pedra. champigny/Marne, França: ICOMOS. 83p. Disponível em: <http://www.icomos.pt/images/pdfs/Glossario_Pedra_I comos.pdf>. Acessado em maio de 2017.

LICCARDO A., PIEKARZ G., SALAMUNI E. 2008. Geoturismo em Curitiba. Mineropar, Curitiba. 122p.

LICCARDO A., MANTESSO-NETO V., PIEKARZ G. 2012. Geoturismo Urbano - Educação e Cultura. Anuário Instituto de Geociências, 35(1):133-141.

MANSUR K.L., CARVALHO I.S., DELPHIM C.F.M., BARROSO E.V. 2008. O Gnaisse Facoidal: a mais Carioca das Rochas. Anuário do Instituto de Geociências, 31(2):9-22. 
NASCIMENTO M.A.L., SILVA M.L.N., BEZERRA G.B. 2016 Centro Histórico da Cidade de Natal: roteiro geoturístico por monumentos construídos com diferentes rochas. Revista Geografia: Conhecimento Prático, 64: 52-59.

PERROTA M.M., SALVADOR E.D., LOPES R.C., D'AGOSTINHO L.Z. 2005. Mapa geológico do Estado de São Paulo, escala 1:750.000. Programa levantamentos geológicos básicos do Brasil, CPRM São Paulo, 2005.

PHILIPP R.P., VARGAS J.A., DI BENEDETTI V. 2009. A memória geológica do centro antigo de Porto Alegre: o registro da evolução urbana nos prédios históricos e no urbanismo da cidade. Pesquisas em Geociências, 36(1):59-77.

PINTO A. 2015. Geodiversidade e Patrimônio Geológico de Salvador: uma diretriz para a geoconservação e a educação em geociências. Tese (Doutorado), Instituto de Geociências, Universidade Federal da Bahia, Salvador, p. 332.

PINTO C.P., DRUMOND J.B.V., FÉBOLI W.L. 2001. Nota explicativa do mapa geológico integrado. Etapa 1. Folhas SE 24-V, SE25-Z, SE24-Y (partes). Belo Horizonte, Projeto Leste, CPRM-COMIG, pp 12-18.

PROCHOROFF R. 2014. Patrimônio geológico de Ilhabela-SP.: estratégias de geoconservação. Dissertação (Mestrado). São Paulo, 2014. 176 p.

REVERTE F.C. 2014. Avaliação da Geodiversidade em São Sebastião - SP, com Patrimônio Geológico. Dissertação (Mestrado), Institudo de Geociências/ USP, São Paulo. 208p.

REVERTE F.C., GARCIA M.G.M. 2016. O patrimônio geológico de São Sebastião - SP: Inventário e uso potencial de geossítios com valor científico. Geociências (São Paulo. Online), 35:495-511.

REYS A.C., DEL LAMA E.A., DEHIRA L.K. 2008. Monumentos da cidade de São Paulo: formas de alteração e conservação. Revista CPC (Centro de Preservação Cultural da USP) 5:93-122.

ROBINSON E. 1982. A geological walk around the City of London-royal exchange to Aldgate. Proceedings of the Geologists' Association 93:225-246.

ROBINSON E. 1984. London: illustrated geological walks. Scottish Academic Press, v.1.

ROBINSON E. 1985. London: illustrated geological walks. Scottish Academic Press, v.2.

ROBINSON E. 1987. A geology of the Albert Memorial and vicinity. Proc Geol Assoc 98:19-37.

ROBINSON E. 1988. A geological walk in Clerkwell, London. Proc Geol Assoc 99:101-124.

ROBINSON E. 1993. A geological walk in Southwark. Proc Geol Assoc 104:285-299.

ROBINSON E. 1997. The stones of the Mile End Road: a geology of Middlemiss country. Proc Geol Assoc 108:171-176.

ROBINSON E., BISHOP C. 1980. Geological walks around St. Paul's. Proc Geol Assoc 91:241-260.

RODRIGUES N.M. 2012. Ensaios não destrutivos em monumentos pétreos paulistanos. Monografia de Trabalho de Formatura. Instituto de Geociências, Universidade de São Paulo (IGc-USP). 75p.

SANTOS P.L.A. 2014. Patrimônio Geológico em Áreas de Proteção Ambiental: Ubatuba - SP. Instituto de Geociências - USP. Dissertação de Mestrado. São Paulo, 207p.

SCIFONI S. 2006. A construção do patrimônio natural. Tese de doutorado. Faculdade de Filosofia, Letras e
Ciências Humanas da Universidade de São Paulo, São Paulo, 294p.

SEADE - FUNDAÇÃO SISTEMA EDUCACIONAL ANÁLISE DE DADOS 2011. Informações dos Municípios Paulistas IMIP. Disponível em: <http://produtos.seade.gov.br/produtos/imp/> acessado em Maio de 2015.

SECTUR - SECRETARIA DE CULTURA E TURISMO 2015. Explorando a História: São Sebastião no tempo. Secretaria de Cultura e turismo, disponível em: <http://turismo.saosebastiao.sp.gov.br/pt/explorando -a-historia/sao-sebastiao-no-tempo> acessado em junho de 2015.

STERN A.G., RICCOMINI C., FAMBRINI G.L., CHAMANI M.A.C. 2006. Roteiro geológico pelos edifícios e monumentos históricos do centro da cidade de São Paulo. Revista Brasileira de Geociências 36(4):704-711.

WEBER P., BAUDIN F., PEREIRA D., CORNÉE A., EGOROFF G., PAGE K. 2016. The Importance of Geosites and Heritage Stones in Cities-a Review. Geoheritage (Publicação Online).
Manuscrito ID 50120

Submetido em janeiro de 2017 Aceito em maio de 2017 